American University Washington College of Law

Digital Commons @ American University Washington College of

Law

Contributions to Books

Scholarship \& Research

$1-1-2009$

\title{
Hunting Promissory Estoppel
}

David V. Snyder

American University Washington College of Law, dsnyder@wcl.american.edu

Follow this and additional works at: https://digitalcommons.wcl.american.edu/facsch_bk_contributions

Part of the Contracts Commons

\section{Recommended Citation}

Snyder, David V. "Hunting Promissory Estoppel” in Mixed Jurisdictions Compared: Private Law in Louisiana and Scotland, edited by Vernon Valentine Palmer and Elspeth Christie Reid, 281-321. Edinburgh Studies in Law Series. Edinburgh: Edinburgh University Press, 2009.

This Book Chapter is brought to you for free and open access by the Scholarship \& Research at Digital Commons @ American University Washington College of Law. It has been accepted for inclusion in Contributions to Books by an authorized administrator of Digital Commons @ American University Washington College of Law. For more information, please contact kclay@wcl.american.edu. 


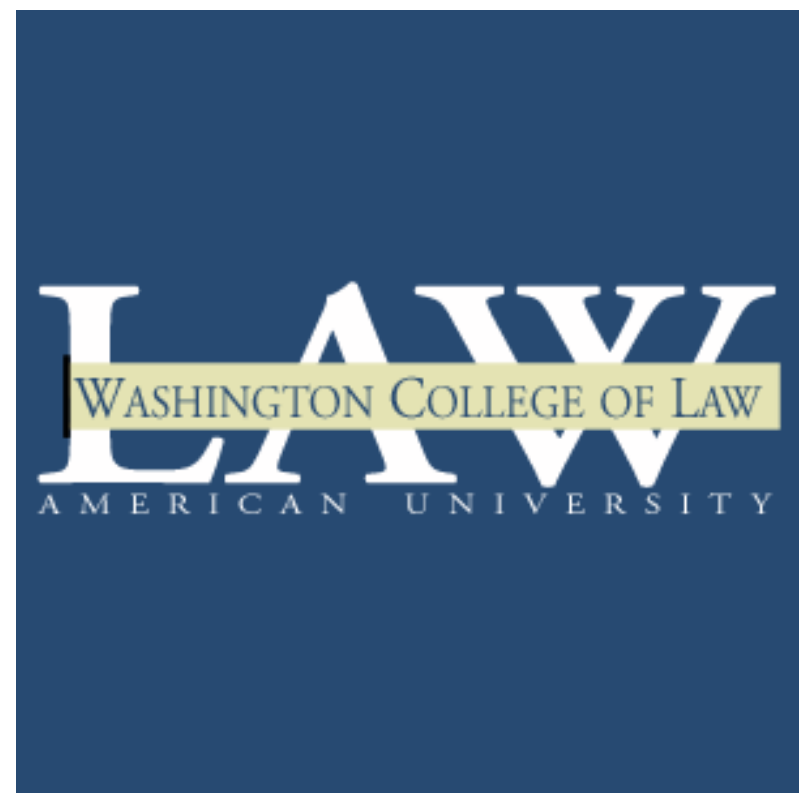

\title{
American University Washington College of Law
}

\author{
Washington College of Law Research Paper No. 2008-86
}

Mixed Jurisdictions Compared: Private Law in Louisiana and Scotland (Vernon V. Palmer \& Elspeth Reid, eds., Vol. 6 of Edinburgh Studies in Law, forthcoming 2009 from Edinburgh University Press)

\section{HUNTING PROMISSORY ESTOPPEL}

\author{
David V. Snyder
}

This paper can be downloaded without charge from The Social Science Research Network Electronic Paper Collection: http://ssrn.com/abstract=1316385 


\title{
HUNTING PROMISSORY ESTOPPEL
}

\author{
David V. Snyder*
}

\begin{abstract}
This paper considers how promissory estoppel jobs are undertaken in two jurisdictions that ought not to need promissory estoppel. The purpose is to achieve a better understanding of systematic decisions to enforce promises and to discover the doctrinal combinations possible in mixed Civil Law / Common Law jurisdictions. This bilateral comparison allows an examination of the different philosophical and moral bases for according promises legal force, whether founded on contract and will or on delict and injury. The differing functions of formalities are also discussed. More particularly, Scotland does not have promissory estoppel but has a remarkable doctrine allowing the enforceability even of unilateral, gratuitous promises. In addition, the Scots law of personal bar, which is similar to estoppel and waiver, fulfils other jobs associated with promissory estoppel. Louisiana, on the other hand, long claimed to reject promissory estoppel but then reversed course and adopted the doctrine about twenty-five years ago. The comparison of these two legal systems affords an opportunity to observe the doctrinal mixes and philosophical choices that have long drawn comparative law scholars to mixed jurisdictions. It also reveals the roles that promissory estoppel can play and how it is not entirely tethered to the problems of the consideration doctrine.
\end{abstract}

Promissory estoppel came into Louisiana law silently, as it pervaded the rest of the United States, under the guises of other doctrines. Even after Williston discovered the hidden current in the American case law and named it 'promissory estoppel' (to distinguish it from equitable estoppel), the doctrine remained unacknowledged in

\footnotetext{
* Copyright @ 2008 David V. Snyder, Washington College of Law, American University, Washington, D.C. Thanks for research assistance go to Rémi Auba Bresson, Drew Cutler, Janette Hays, and Diana Verm, and I am grateful as always to the amazingly resourceful Adeen Postar of the Pence Law Library, and to the other fine professionals there, particularly Y. Renée Talley-Cuthbert. I would like to note my special gratitude to Hector MacQueen and Elspeth Reid, my mentors in this project; Laura Macgregor, who made a special effort to help me understand Scots law and its institutions; as well as to Vernon Palmer and the other organizers and participants in the Louisiana-Scotland project, who provided more assistance than can be catalogued here. Many errors no doubt remain, and they are mine alone.

In keeping with the editors' injunction, I have endeavoured to minimize footnotes. In that effort I have often relied on certain central sources that I try to acknowledge prominently but not repeatedly. Readers should realize that this practice may depart from the usual expectations of American legal writing.
} 
Louisiana law. With its Civil Law heritage Louisiana had no need to fix Common Law problems, it was thought, and promissory estoppel was only a tool for Common Law repairs. This thinking turned, though, and the state has now enshrined promissory estoppel in the Civil Code. The story is touched by drama, with misperception and disguise, the arch of character development and retrenchment, changes of view and of heart, and a conclusion gilded by triumph and tinged with ambiguity.

The drama in Louisiana law comes from the relationship of Common Law and Civil Law in a hot, fecund setting. One may well hope that the cooler moisture of Scotland, which has produced more than its share of drama amid the mix of romantic settings and careful rationalists, would also produce an engrossing but different story of legal mixture. In Scotland, even Adam Smith and David Hume interested themselves in promises and their place in the law, and in Smith's case, the Scots law in particular. ${ }^{1}$ With this background, the subject seemed an enticing prospect for an interesting story. For this I have gone looking, and I now want to explain what I have found. As a study of two mixed jurisdictions, the story told in this chapter, like in the rest of the book, is necessarily an examination of a relationship between two sets of relationships. As might be imagined, the stories make an intricate and complex braid.

\section{A. APOLOGIA FOR A DOCTRINAL STUDY OF PROMISSORY ESTOPPEL}

Promissory estoppel is marked by three characteristics that make it peculiarly interesting for comparative study. Its father was the strict doctrine of consideration, and its mother was the just pressure to decide cases fairly despite technical strictures. Its growing up was shaped profoundly by the death of its old fashioned but generous grandparent the seal,

\footnotetext{
${ }^{1}$ W W McBryde "Promises in Scots Law” (1993) 42 Intl\&CompLQ 48 at 57-59.
} 
which honoured gratuitous promises but only so long as they were sufficiently cloaked in formality. This ancestry, comprised of distinguishing doctrines of the Common Law and the case method of legal development, would seem to destine promissory estoppel for a life only within thoroughly Common Law systems. Yet its presence in Louisiana law over many decades, and its spectacular introduction into the Civil Code in the late twentieth century, would suggest that the power of the doctrine-long a source of concern to scholars who thought it might just kill the whole of contract law-would propel it into the worlds of mixed jurisdictions, at least, and perhaps the Civil Law itself.

Second, promissory estoppel is the closest that the Common Law comes to recognizing the moral core of a promise. With the consideration doctrine, the Common Law seems to hold that a promise in the eyes of the law is only worthwhile if someone else is paying for it. Moreover, the worth of the promise is typically defined only in monetary terms. While the latter point needs little rehearsal, in American scholarship it has become sharpened by the literature that spins contracts into options either to perform or to pay damages. ${ }^{2}$ How systems outside the relatively pure jurisdictions in England and the United States treat unbargained-for promises may cast light on the presence or absence of moral fibres running through the legal treatment of promises, and the strength and orientation of those sometimes hidden threads. This chance for close observation brings up the possibility of shedding more light on the familiar and related last point.

The moral implications of promise can be seen in two ways: the moral need for the promisor to adhere to the promise, and the moral impetus to protect a promisee who has been harmed by a broken promise. Put this way, the third point becomes apparent, as promissory estoppel can be conceived more as a doctrine of tort than of contract. Framed

\footnotetext{
${ }^{2}$ See, e.g., A W Katz, “The Option Element in Contracting” (2004) 90 VaLRev 2187.
} 
in these terms the issue seems legal and technical, but stripped of its legal jargon the question seeks a revelation about whom the law seeks to protect and what interests are deemed worthy of legal protection. A close look, then, might reveal the moral warp and woof of the law's choices: the promisor's duty, which is a consequence of his own freedom and the dignity of his will, is woven through the promisee's right, which is a consequence of his injury, whether real, potential, or conceptual. There are few questions more fundamental, and the law's treatment of unbargained-for promises again would seem an attractive path for research that would enable a better understanding of systemic commitments in different jurisdictions.

Having these questions in mind, then, an excursion into the law of promises would seem likely to be rewarding. At the same time, it must be admitted that the project is unusual in its formulation. The centre of the inquiry is a doctrine, and this design would seem to ignore the insights offered by Rudolf Schlesinger and the followers of the Cornell method. ${ }^{3}$ This study, though, while now unorthodox in its doctrinal focus, does not ignore their teachings. Promissory estoppel will remain at the centre, but the focus will be on the kinds of 'jobs' that the doctrine is expected to do, and how those legal jobs are undertaken in Louisiana and Scotland. The examination, of course, will take place in a doctrinal light inevitably filtered through the omnipresences of American and English Common Law, with which both of the smaller jurisdictions have to contend.

The greater project here, after all, is a bilateral comparison of two mixed jurisdictions, and the mixed nature of the systems is a key component of the study. In this regard, a fourth point can be added to the three characteristics of promissory estoppel

\footnotetext{
${ }^{3}$ See generally R B Schlesinger (ed) Formation of Contracts: A Study of the Common Core of Legal Systems (1968).
} 
mentioned above: perhaps by happenstance, the Louisiana and Scottish law relating to unbargained-for promises allows an extraordinary insight into the mixing of policies, doctrines, and attitudes, along with the peculiar sources of law in these two mixed jurisdictions. In Stair's institutional analysis of promises and contracts, and in the Louisiana State Law Institute’s careful debate on promissory estoppel, observers may witness just the kind of mixing that imports select ingredients, alters them to suit local taste, and lets the transformation of the import adapt and grow in a new environment. This is what I have been hunting, and I believe that I have found it in the law of promises, whether they be couched in terms of promissory estoppel and detrimental reliance or unilateral obligations and personal bar.

\section{B. FUNDAMENTALS}

This kind of study needs to be built from fundamentals, and the relation of promissory estoppel to some of the basic tenets of legal systems-tenets like consideration, cause, and promise - is part of the attraction of this inquiry. To understand each of these relationships, the components in each system need to be established and evaluated. We begin with the Common Law, especially the American law of promissory estoppel, but with some reference to its English counterpart. With that foundation, the mixed approaches in Louisiana and Scotland can be examined.

\section{(1) Promissory estoppel in the United States and England}

Promissory estoppel appears in its most important current formulation in the Restatement (Second) of Contracts (1981): 


\section{$\S$ 90. Promise Reasonably Inducing Action or Forbearance}

(1) A promise which the promisor should reasonably expect to induce action or forbearance on the part of the promisee or a third person and which does induce such action or forbearance is binding if injustice can be avoided only by enforcement of the promise. The remedy granted for breach may be limited as justice requires.

(2) A charitable subscription or a marriage settlement is binding under Subsection (1) without proof that the promise induced action or forbearance.

This provision in the second Restatement adds a few fillips to the influential introduction of the doctrine in the first Restatement (1932). The essential features, though, remain. ${ }^{4} \mathrm{~A}$ promise and detrimental reliance on it are both required, except in cases involving charitable subscriptions (and the now rare marriage settlement), and the equitable and exceptional nature of the rule appears expressly. Presumably the periphrastic negative phrasing of the requirement of injustice is meant to emphasize that promissory estoppel is a last resort.

The evolution of the doctrine is both interesting and important, but current constraints require that it be told quickly and simply, perhaps overly so. Promissory estoppel, as hinted before, is the child of the strict consideration doctrine. How consideration came to be understood according to a rigid bargain theory is a curious matter, but however it happened, the development was crystallized in the first Restatement of Contracts. Consideration required a bargain, that is, that the parties mutually induce each other with their promises or performances. At about the same time, formal contracts ceased to matter as the seal became outmoded. Thus there could be no

\footnotetext{
${ }^{4}$ Much of the information on the history of promissory estoppel in the United States and in Louisiana can be found in more detail and with more elaborate citation in my earlier article, D V Snyder, "Comparative Law in Action: Promissory Estoppel, the Civil Law, and the Mixed Jurisdiction” (1998) 15 ArizJIntl\&CompL 695 (1998), reprinted in V V Palmer (ed) Louisiana: Microcosm of a Mixed Jurisdiction (1999) ch 10.
} 
consideration, and no enforceable contract, unless both parties were seeking the other's promise or performance.

So put, however, the results of countless cases could not be explained. In recognition of this strong trend within the common law, which the reporter for the Restatement had himself discovered, the honest Restatement recognized a doctrine of promissory estoppel. To be enforceable, then, a promise would have to be part of a contract supported by consideration (meaning a bargained-for exchange) or would have to lie within the saving reach of the newly legitimized promissory estoppel. The sponsors of the Restatement saw that the courts applying the common law would not be rigidly constrained by an inflexible bargain theory, and promissory estoppel provided an escape should the circumstances of a case prove sufficiently compelling.

The birth of promissory estoppel, of course, is only the beginning, and the doctrine has grown. For a time some influential thinkers restricted it to use outside business transactions, reasoning that in a commercial setting consideration should present no difficulty, and the parties could protect themselves through contracts. '[I]t does not in the end promote justice,' the influential Learned Hand wrote, to protect 'those who do not protect themselves. ${ }^{5}$ This restriction withered with the generation that propounded it, though, and by the time of Justice Traynor, it had perished. The California Supreme Court in Drennan v Star Paving Co. ${ }^{6}$ was perfectly willing to bring promissory estoppel to the rescue of general contractors disappointed by the withdrawal of a subcontractor's bid-the very context in which Learned Hand had written his well known lines. No longer confined to promises of family members and grateful employers, then, promissory

\footnotetext{
${ }^{5}$ James Baird Co v Gimbel Bros 64 F2d 344 at 346 (2d Cir 1933).

${ }^{6} 333$ P2d 757 (Cal 1958).
} 
estoppel seemed destined to displace consideration, which no one had loved much anyway, and famous pronouncements of death predictably ensued. ${ }^{7}$

Consideration and the seal are not the only relevant doctrines. Just as the rigidities of consideration could create pressure for escape, similarly rigid formal requirements could do the same. Some contracts, to be enforceable, must be in writing under the Statute of Frauds and its progeny, but sometimes strict adherence to writing requirements seems to lead to injustice. Decisions confronting such facts led eventually to a number of exceptions to the statute, but such situations also led some courts to allow a more general residual escape based on promissory estoppel. This phenomenon received express recognition in section 139 of the Second Restatement; it had not appeared in the first Restatement, ${ }^{8}$ although the case law to support the idea was arguably present already. After all, the formal requirements of the Statute of Frauds (1677) were stated with brittle clarity far before the once-cloudy consideration doctrine hardened into the bargain form and long before the American Common Law lost the seal.

Particularly because of its potential relevance to the Scottish side of this project, promissory estoppel in England also deserves mention. ${ }^{9}$ The middle of the nineteenth century witnessed the liberalization in various English doctrines of estoppel, ${ }^{10}$ but that case law saw little use in the twentieth century until Lord Denning's judgement in Central London Property Trust Ltd. v High Trees House, Ltd. ${ }^{11}$ Later cases, including prominent opinions from Lord Denning, developed the doctrine, although it retained its

\footnotetext{
${ }^{7}$ Grant Gilmore, The Death of Contract (1974).

${ }^{8}$ See Restatement (Second) of Contracts § 139 reporter's note.

${ }^{9}$ I have primarily followed Joel M. Ngugi "Promissory Estoppel: The Life History of an Ideal Legal Transplant” (2007) 41 URichmondLRev 425 at 467, as my source on English law.

${ }^{10}$ See particularly Hughes v Metropolitan Ry Co [1877] 2 AC 439 (HL), and Birmingham \& Dist Land Co v London \& NW Ry Co 40 ChD 268 (CA 1888).

${ }^{11}$ [1947] KB 130 at 135 (1946).
} 
roots in estoppel and thus could not ground a cause of action, being inherently a defence to other obligations. ${ }^{12}$ Although this kind of estoppel, referred to occasionally by the forthright 'promissory estoppel' label, is now well established, ${ }^{13}$ it remains tethered to its defensive conception and is therefore often said to be a shield rather than a sword. ${ }^{14}$ English law arguably employs a less constricted doctrine of consideration than American law, however, which may diminish the need for offensive promissory estoppel. ${ }^{15}$ Nevertheless, some suggest that under the influence of Australian law, which itself was influenced by the American Restatements, English law may move toward an expanded notion of promissory estoppel closer to American lines. ${ }^{16}$

\section{(2) A historical introduction to promissory estoppel in Louisiana law}

\section{(a) Cause and consideration in Louisiana law}

Louisiana, it might be said dogmatically, has no doctrine of consideration, so one might think that promissory estoppel would have no role in the state. The dogma, however, is misleading, and it can be traced most clearly to sources other than the Civil Code for the vast majority of the state's legal history. The problem, indeed, was that the Civil Code

\footnotetext{
${ }^{12}$ See Combe v Combe [1951] 2 KB 215 (CA).

${ }^{13}$ See Ajayi v R T Briscoe (Nigeria) Ltd [1964] 1 WLR 1326 (PC).

${ }^{14}$ See First Natl Bank PLC v Thompson [1996] Ch 231 (CA) (rejecting unitary approach to estoppel, which would allow offensive use of the doctrine to protect promises); see also Republic of India v India S S Co [1998] AC 878 at 914 (HL). Compare Amalgamated Inv \& Prop Co v Texas Commerce Intl Bank Ltd [1982] QB 84 at 122 (CA) (Denning MR) (Estoppel was 'limited by a series of maxims: estoppel is only a rule of evidence, estoppel cannot give rise to a cause of action, estoppel cannot do away with the need for consideration, and so forth. All these can now [after 150 years of evolution] be seen to merge into one general principle shorn of limitations.'). For the armorial analogy, see the opinion of Birkett LJ in Combe at 224.

${ }^{15}$ See A T Denning “Recent Developments in the Doctrine of Consideration” (1952) 15 ModLRev 1 at 1-2.

${ }^{16}$ The seminal Australian case is Waltons Stores (Interstate) Ltd v Maher (1988) 164 CLR 387, and the English courts have begun to cite it and its progeny, see Ngugi (n 9) at 492 \& n 411 . See generally ibid at 485-493. The expansiveness of proprietary estoppel can also seem to have considerable offensive capacity, not far removed from American promissory estoppel. See e.g. Wayling v Jones 1995 FLR 1029; E C Reid \& J W G Blackie, Personal Bar (2006) 95f. For a different viewpoint, see Roger Halson, "The Offensive Limits of Promissory Estoppel” [1999] Lloyd'sMar\&CommlLQ 256.
} 
itself contained the problematic word consideration, both in the central definition of cause and in other troublesome places.

Nowhere was worse, obviously, than in the main definition of cause. 'By the cause of the contract,' the Civil Code of 1870 provided, 'is meant the consideration or motive for making it. ${ }^{17}$ The Civil Code of 1825 was the source for the 1870 provision, and the 1825 French version gave this definition: 'On entend par la cause du contrat ... la considération ou le motif qui a engagé à contracter. ${ }^{18}$ If this were not enough, consideration received another explicit mention in the Code just where it creates some of its most obstreperous problems in the Common Law: with respect to options. (Note that the minor differences between options and irrevocable offers are ignored in this chapter, and both are referred to as options.) From the early twentieth century until 1985, the relevant articles read, 'One may purchase the right, or option to accept or reject, within a stipulated time, an offer or promise to sell, after the purchase of such option, for any consideration therein stipulated, such offer, or promise can not be withdrawn before the time agreed upon ...., ${ }^{19}$

All of this fomented a fair amount of Civilian angst in Louisiana, proud of its Civil Law heritage but having to cope with its location in a Common Law country. Efforts nevertheless were made to reconcile these mentions of consideration with the indisputably Civilian notion of cause. In general, Professor Litvinoff sought to show,

\footnotetext{
${ }^{17}$ La Civ Code art 1896 (1870).

${ }^{18}$ See art 1887 of the Civil Code of 1825 . Where the Code of 1825 is the source, the French version is considered more authoritative than the English versions of either 1825 or 1870. E.g. Ross v La Coste de Monterville 502 So2d 1026 at 1029-30 (La 1987) (citing, inter alia, Shelp v Natl Surety Corp., 333 F2d 431 (5th Cir 1964)).

${ }^{19}$ The quoted text reflects amendments through 1920 to article 2462 of the Code of 1870 . The problematic introduction of consideration or 'value' seems to have occurred during amendments in 1910, see Acts 1910, no. 249, and 1920, see Acts 1920, no. 27. See generally Joseph Dainow (ed), Compiled Edition of the Civil Codes of Louisiana vol 2 (1972) 105-106.
} 
'consideration' as used in the Code could be read to be 'at times synonymous with “cause," and other times with “onerous cause.”, ${ }^{20}$ He then argued that the requirement that there be ‘any consideration' for an option would be satisfied in virtually every option, given that the parties are interested in buying or selling, particularly since the flexible 'any consideration therein stipulated' formulation replaced the earlier, stricter requirement that the option be 'purchase[d] ... for value. ${ }^{, 21}$ These arguments, while based on undoubted facts, suggested strenuous interpretation that was not the more convincing for its heroism. And despite such scholarly arguments, Louisiana courts unhesitatingly required that an option be supported by consideration, much as at Common Law. ${ }^{22}$

At the same time, Louisiana did recognize certain kinds of conventional obligations without any consideration at all, as long as formal requirements were met. Although the American Common Law had lost an efficacious seal, Louisiana retained the possibility of a valid gratuitous contract, that is, a promise of a donation. The English version of the article included a defining reference to consideration ('without any profit or advantage, received or promised as a consideration for it'), but this was not entirely faithful to the original French ('sans aucun profit ni avantage stipulé en faveur de l'autre

\footnotetext{
${ }^{20}$ Saúl Litivinoff, Obligations vol 2 (1975) s 107.

${ }^{21}$ A fuller quotation of the 1910 version may be helpful: 'One may purchase the right, or option, to accept or reject, within a stipulated time, an offer or promise to sell. After the purchase of such option, for value, such offer or promise can not be withdrawn before the time agreed upon ....' Note that I do not mean to imply that consideration came into Louisiana law only in the early twentieth century. It goes back at least to the early nineteenth. See Heirs of Cole v Cole's Exrs 7 Mart (ns) 414 (La 1830) ('defendants denied the consideration, and the court below being of opinion, that none had passed between the parties, gave judgment').

${ }^{22}$ See Goodyear Tire \& Rubber Co v Ruiz 367 So2d 79 (La Ct App 4th Cir 1979) (option invalidated as nudum pactum); see also McCarthy v Magliola 331 So2d 89 (La Ct App 1st Cir 1976) (upholding option after finding it supported by consideration). Older cases also so held. See, e.g., Glover v Abney 106 So 735 (La 1925) (option without consideration not binding); Moresi v Burleigh 127 So 624 (La 1930) (holding \$100 sufficient consideration); Davis v Bray 191 So2d 774 (La Ct App 2d Cir 1966) (same).
} 
partie'). ${ }^{23}$ In any event, the reference to consideration did not cause any difficulty in this case, and Louisiana law recognized even a fully gratuitous contract as a donation inter vivos. Two requirements had to be met. First, the intent had to be expressed in a so-called authentic public act, that is, a writing 'passed before a notary public and two witnesses.'24 Second, the promise had to be accepted. ${ }^{25}$ Louisiana here followed the French idea of cause, classifying the obligation as gratuitous but still allowing it, with formal requirements. This situation obtained at the same time as various mentions of consideration in other contexts muddied the Louisiana waters on whether the courts would follow the doctrine of cause exclusively or would revert to ideas of consideration. The legal situation in Louisiana was decidedly mixed.

Cleanup occurred in the revision of the Civil Code that became effective in 1985, reflecting the mid- to late-century Civilian renaissance that Louisiana had enjoyed, much as Scotland did. References to consideration were excised, and consideration doctrine was expelled in clear terms. After requiring cause and defining it, without reference to consideration, the comment to the revision states: 'Under this Article, “cause” is not “consideration.”, ${ }^{26}$ With respect to options, the revision requires no consideration, and the revision commentary states, with a certain amount of gumption, that the revision 'does not change the law. ${ }^{27}$ Anyone reading the new article on the irrevocability of offers would not know of the consideration difficulties of three-quarters of a century. And the reference to consideration in the article on gratuitous contracts was also removed,

\footnotetext{
${ }^{23}$ The English text is the same in the Codes of 1825 (art 1766) and 1870 (art 1773). The French text comes from the 1825 Code.

${ }^{24}$ La Civ Code arts 1536, 1538. French law is similar, requiring a notarial act. See C civ art 931.

${ }^{25}$ La Civ Code arts 1540-1543.

${ }^{26}$ See ibid arts 1966 (requiring cause), 1967 (defining cause) \& cmt (c).

${ }^{27}$ See ibid art 1928 \& cmt (a).
} 
without mention, with the usual comment that the revised article 'does not change the law. ${ }^{28}$

\section{(b) Promissory estoppel in Louisiana}

As in the Common Law states, promissory estoppel got its start in late nineteenth-century case law in which the equities of the case seemed to require enforcement of a promise that did not amount to the usual kind of contract. In Choppin v Labranche, the Louisiana Supreme Court enforced a promise to leave in peace the remains of the plaintiff's ancestor. $^{29}$ A number of cases also enforced promises on grounds that could be rationalized under the terms of promissory estoppel. To be sure, the cases did not use the 'promissory estoppel' label; courts arrived at these results through a variety of devices and could hardly be expected to use the name, which had not yet been invented. So in the early Louisiana law, promissory estoppel percolated quietly through the cases, as elsewhere in the country.

The more interesting development occurred in the 1950s, when the Louisiana Supreme Court considered promissory estoppel in Ducote $v$ Oden. By that time the doctrine had not only a name but also a renowned imprimatur from the American Law Institute. After repeating counsel's argument, which sounded the very words of the Restatement, the court remarked that '[s]uch a theory is unknown to our law' and could not be found in the all-important 'provisions of the Civil Code. ${ }^{30}$ The holding is not as square as it might be: The court emphasized the weakness of the plaintiff's allegation that

\footnotetext{
${ }^{28}$ See ibid art 1910 \& cmt (a).

2920 So 681 at 682 (La 1896).

${ }^{30}$ Ducote v Oden, 59 So2d 130 at 132 (La 1952).
} 
the promise took place in a 'casual . . . conversation in the stages of discussion,' ${ }^{31}$ and even courts which accept the doctrine would likely find that the elemental 'promise' had not been shown. Nevertheless, for many years Ducote was taken as a rejection of the Common Law doctrine, perhaps a case of an opinion coming to stand for a broader and more certain holding than the court had originally intended.

Eventually, this position would be reversed by the Civil Code. The Louisiana State Law Institute decided to include promissory estoppel in the 1984 revision, and in particular, in the central definition of cause. How this shift occurred is crucial to the present inquiry and will be examined in more detail below. For the moment, it is enough to see the product of the Institute debates, which appears in the current Civil Code:

\section{Art. 1967. Cause defined; detrimental reliance}

Cause is the reason why a party obligates himself.

A party may be obligated by a promise when he knew or should have known that the promise would induce the other party to rely on it to his detriment and the other party was reasonable in so relying. Recovery may be limited to the expenses incurred or the damages suffered as a result of the promisee's reliance on the promise. Reliance on a gratuitous promise made without required formalities is not reasonable.

The revision comments say that Ducote 'is thus overruled.' Since the revision, dozens of cases have applied or considered article 1967.

\section{(3) Promise and personal bar in Scotland}

The doctrinal landscape in Scotland shares certain core characteristics with Louisiana but in some ways it is considerably different. The law of promise and of personal bar are the doctrines most relevant to this inquiry. The law of promise is intriguing but slender. The scope of personal bar, which in American terms seems like all of estoppel and waiver

\footnotetext{
${ }^{31}$ Ibid at 131-132.
} 
rolled into one (although this perception oversimplifies matters), is vast. ${ }^{32}$ We begin with a short look at both, starting with promise.

(a) The Scots law of promise

Although promises are central to countless legal systems of obligations, the naked promise, unadorned by consideration or even acceptance, is a special creature. Usually welcomed into legal confines with about as much enthusiasm as other streakers, ${ }^{33}$ Scotland is a special case. For hundreds of years Scots law has recognized the binding force of at least some promises, even though they are unaccepted by the beneficiary and unsupported by consideration. Indeed, the lack of acceptance, or any need for it, is the only way to distinguish a promise from a contract in Scots law, since there is no requirement of consideration. ${ }^{34}$ The distinctive Scots law of promise, at least at first, would seem to preclude any place for promissory estoppel or its analogues. ${ }^{35}$ One

${ }^{32}$ See Reid \& Blackie, Personal Bar (n 16) at 54-69.

${ }^{33}$ Robertson v HM Adv [2007] HCJAC 63 (the case of the naked rambler).

${ }^{34}$ Unlike Louisiana, Scotland has not generated great doctrinal or theoretical confusion in this regard, but consideration is not entirely irrelevant. Lord Caplan, for instance, declines to find a promise in Gordon $v$ East Kilbride Development Corp, 1995 SLT 62 at 64 (28 Nov 1990), partly because the lack of consideration flowing to the alleged promisor makes a true obligatory promise too unlikely.

${ }^{35}$ My principal sources on promise have been: W W McBryde, The Law of Contracts in Scotland 3d edn (2007) ch 2, and as to proof by writ or oath, the first edition (1987) paras 2-42 to 2-47 and 27-20; McBryde (n 1); W D H Sellar "Promise", in K Reid \& R Zimmermann (eds) A History of Private Law in Scotland: Obligations vol 2 (2000) 252. I understand that McBryde is thought to be most authoritative, at least by practitioners. See H L MacQueen \& J Thomson, Contract Law in Scotland 2d edn (2007) para 1.52, which I have also consulted (primarily paras 2.54-2.63). A thorough theoretical discussion appears in Martin Hogg, Obligations 2d edn (2006) ch 2. German readers will be interested in R Zimmermann \& P Hellwege “Belohnungsversprechen: 'pollicitatio', 'promise’ oder 'offer'?: Schottisches Recht vor dem Hintergrund der europaischen Entwicklungen” 1998 ZfRV 133. My main source on personal bar is Reid \& Blackie, Personal Bar (n 16), and I have considered J Rankine, The Law of Personal Bar in Scotland (1921) superseded. See also H L MacQueen \& W D H Sellar "Scots Law: Ius quaesitum tertio, Promise and Irrevocability”, in E J H Schrage (ed) Ius Quaesitum Tertio (2008) 357. While I have not had occasion to rely on it for specific points, J P Dawson's famous Gifts and Promises: Continental and American Law Compared (1980) has helped shape my interest and approach. For a purely American approach to similar problems in light of new scholarship, see M B Wessman "Recent Defenses of Consideration: Commodification and Collaboration” 41 IndLRev 9 (2008) (arguing for enforcement of gratuitous promises and criticizing the requirement of consideration and the new arguments in its support). 
significant wrinkle, however, bears mention at this stage: until 1995 gratuitous promises had to be proved by writ or oath. So perhaps they were not so naked after all. Moreover, particular kinds of commercial obligations might have to be constituted or proved formally, such as cautionary obligations (i.e., contracts of suretyship). ${ }^{36}$ These formal requirements would seem to beg for an antidote in appropriate cases.

\section{(b) Personal bar and allied doctrines}

And so it was, at least to some degree, and so it is. Before 1995, two common law rules sometimes rescued obligations suffering from formal defects in their constitution. If the promisee, with the promisor's knowledge, relied on the defective agreement as if it were valid, then the promisor was bound as long as his conduct was 'unequivocally referable to the agreement. ${ }^{37}$ This rule was called rei interventus and sounds quite similar to promissory estoppel when promissory estoppel is used to cure defects arising from the statute of frauds. A second rule, homologation, bound the promisor when he himself showed that he accepted the defective contract as valid. It sounds similar to the American and English rules on ratification.

Homologation and rei interventus were limited, however, to defects in the constitution of the obligation and could not be used to remedy defects in proof. This meant that some obligations, which did not legally exist without a writing, could nonetheless be deemed to exist. Other obligations_-including gratuitous promises_- did not require a writing for their constitution, but had to be proved by writ or oath. For that reason, homologation and rei interventus could not save the distinctive Scottish promise

\footnotetext{
${ }^{36}$ Mercantile Law Amendment (Scotland) Act 1856 s 6.

${ }^{37}$ Bell, Prin § 26.
} 
if it were not in writing or were not confessed under oath. ${ }^{38}$ This would seem to tie Scots law to Louisiana law: both systems allow enforceable gratuitous promises, unlike the Common Law, because no consideration is required. A formality, however, is necessary (and, in the case of Louisiana, so is acceptance). Since the law in both places allows promises unhampered by rules on consideration, promissory estoppel and analogous rules like homologation and rei interventus might be thought unnecessary.

In another light, though, the state of affairs in Scotland seems surprising. Homologation and rei interventus were recognized sometimes, after all. A person could be deemed bound although he was not in fact obligated in the eyes of the law, provided the elements of homologation or rei interventus were satisfied. Yet in the eyes of the law he was released from a real and validly constituted obligation, simply for want of adequate proof, even if the elements of homologation or rei interventus were satisfied. This result is no less remarkable because it seems to flow from a technical distinction between the constitution and the proof of an obligation. ${ }^{39}$

But the most prominent point here is that the rule in Scotland was not softened if there had been detrimental reliance on the promise. ${ }^{40}$ This result might be explained away, though, on two grounds. I am only aware of a few cases so holding, almost all of which are old (1911 and 1928) or even antique (1771 and 1861). Views of the equities of

\footnotetext{
${ }^{38}$ See Reid \& Blackie, Personal Bar (n 16) ch. 7, especially at 123-24. This statement appears true at least if the promise were not ancillary to a contract susceptible of proof by parol. See McBryde, Contracts 1st edn (1987) (n 35) at 25.

${ }^{39}$ This distinction is not present in Louisiana. See La Civ Code art 1536 (donation must be in proper form 'under penalty of nullity'), 1538 (donation 'will not be valid' without requisite form); see also Civil Code of 1825, arts 1523 ('sous peine de nullité'), 1525 ('ne sera valable').

${ }^{40}$ Gray v Johnston 1928 SC 659; Smith v Oliver 1911 SC 103 (10 Nov 1910); Edmondston v Edmondston (1861) 23 D 995; Millar $v$ Tremamondo 1771 M 12, 395. The only recent case I know is from the Sheriff's Court. McEleveen v McQuillan's Ex'x 1997 Sh Ct 46. On the matters of proof by writ or oath, I have relied on A G Walker \& N M L Walker, The Law of Evidence in Scotland (1964), most particularly s 130, but also ch 11 in general, at 113-134.
} 
promises and reliance may have changed over periods that can best be measured in centuries. Also, the more recent high court cases (1911 and 1928), as well as the sheriff's court case that is the sole decision in memory (1997), all concerned wills, and as Lord President Dunedin observed in one of them, it would 'be a most extraordinary result' if promises to make wills could be informal when wills themselves had to be written. ${ }^{41}$

Homologation and rei interventus were not the only tools at the disposal of the courts. The memorably named doctrine of Melville Monument liability can also come to the rescue. ${ }^{42}$ In the seminal case, Walker and his father were developing the New Town of Edinburgh on Walker's estate. Milne led a group of subscribers who planned to erect a monument to Viscount Melville, and they entered the estate with Walker's permission, where they broke the land and undertook other preparations. They also interfered with Walker's plan for the development of the estate before deciding to put the monument in St. Andrew Square, where it still stands. When Walker sued, Milne objected that the contract involved heritage (rights in land) and was invalid because it was unwritten. The court nevertheless allowed Walker to recover any expenditure he had wasted on account of the relocation of the monument.

Melville Monument liability looks very much like promissory estoppel, especially on the facts of Walker $v$ Milne. One of the long-time jobs of the doctrine was to solve problems caused by writing requirements, which were precisely the problem in Walker. The facts of the case highlight two other points as well. First, the case is not about a promise but about an invalid contract, a result of the parties having proceeded by mutual agreement as opposed to unilateral declaration. This semantic nicety does not distinguish

\footnotetext{
${ }^{41}$ Smith v Oliver 19102 SLT 304 at 306, 1911 SC 103 at 111.

${ }^{42}$ Walker v Milne (1823) 2 S 379 (new ed 338). See generally MacQueen \& Thomson, Contracts (n 35) paras 2.93-2.96.
} 
it from American promissory estoppel, however, but merely reflects a different usage. Scots law limits promise to unilateral obligation, while American law often speaks of contractual agreements in terms of (reciprocal) promises. Certainly many promissory estoppel cases involve apparent agreements rather than simple and pure unilateral declarations.

Second, the facts suggest charity or gratuity. It may well be that the agreement could be characterized as being supported by consideration, or as an onerous and synallagmatic contract. Perhaps Walker wanted to grace the New Town development with an attractive monument to Lord Melville, and maybe thought it would add value to the venture. Milne and the subscribers certainly wanted a place to put the monument, and perhaps the parties agreed to a bargain based on those desires. But the erection of a monument supported by subscriptions and Walker's dedication of land without monetary payment indicate that this undertaking was essentially eleemosynary. This fact-situation is a second way in which Melville Monument liability, in the defining case, could be seen as a kind of promissory estoppel.

While Walker v Milne was followed in the nineteenth century, current judicial attitudes seem anxious to keep the liability exceptional, and 'any tendency to extend the scope of the remedy is to be discouraged. ${ }^{43}$ In retrospect, this sceptical judicial view can be detected early, as in Gray v Johnston, where the majority sees Melville Monument liability subsisting in the cold shadow of the defective contract, ${ }^{44}$ and where the only sympathetic treatment comes in Lord Justice Clerk Alness's dissent. ${ }^{45}$ So any such liability should be limited, recent authority holds, to situations where the promisor has at

\footnotetext{
${ }^{43}$ Dawson Intl plc v Coats Patons plc, 1988 SLT 854 at 865 affd 1989 SLT 655.

441928 SLT 499 at 505 per Lord Ormidale.

${ }^{45}$ See ibid at 508.
} 
least impliedly assured the other party that there is a binding contract. ${ }^{46}$ If the parties are still negotiating, then, they are immune from Melville Monument liability. The potential for Melville Monument liability remains as a saving doctrine for defective contracts, though, and it may be conceived as a branch of personal bar. ${ }^{47}$ Whether it will become a powerful tool for redress of defective contracts or will instead be confined to the rare evocative case is an open question, but the latter at this point seems more likely. ${ }^{48}$

Recent scholarly work has done much to rationalize the law of personal bar, which provides a largely defensive remedy for inconsistent conduct that causes unfairness. It is summarized in the following schema by Elspeth Reid and John Blackie:

\section{(A) INCONSISTENCY}

(1) A person claims to have a right, the exercise of which the obligant alleges is barred.

(2) To the obligant's knowledge, the rightholder behaved in a way which is inconsistent with the exercise of the right. Inconsistency may take the form of words, actions, or inaction.

(3) At the time of so behaving the rightholder knew about the right.

(4) Nonetheless the rightholder now seeks to exercise the right.

(5) Its exercise will affect the obligant.

\section{(B) UNFAIRNESS}

In the light of the rightholder's inconsistent conduct, it would be unfair if the right were now to be exercised. Any of the following is an indicator of unfairness:

(1) The rightholder's conduct was blameworthy.

(2) The obligant reasonably believed that the right would not be exercised.

(3) As a result of that belief the obligant acted, or omitted to act, in a way which is proportionate.

\footnotetext{
${ }^{46}$ See Dawson 1988 SLT at 862-65.

47 See Gray v Johnston 1928 SC 659 at 676 (Alness LJC dissenting); Reid \& Blackie, Personal Bar (n 16) at 96 n 82; see also John Blackie, "Good Faith and the Doctrine of Personal Bar”, in A D M Forte (ed) Good Faith in Contract and Property (1999) 129 at 153-55 (noting that personal bar is generally only a shield from liability while the Melville Monument theory is not so limited, suggesting that it is perhaps closer to promissory estoppel than to personal bar).

${ }^{48}$ Since Dawson, the doctrine has made only token reappearances, as in Bank of Scotland v 3i Plc 1990 SC 215 and in McMillan v Ghaly, unreported, Dundee Sh Ct, 9 Sept 2002.
} 
(4) The exercise of the right would cause prejudice to the obligant which would not have occurred but for the inconsistent conduct.

(5) The value of the right barred is proportionate to the inconsistency. ${ }^{49}$

It may fairly be observed at this point that if Scotland did observe some kind of

promissory estoppel, it would fall reasonably neatly within this schema, with one possible exception.

The main difficulty is point (A)(3), which suggests that the promisor must know that his promise is not legally binding before he will be held estopped from shrinking back from his promise. To the extent legal knowledge is a strict requirement, it could differentiate personal bar from promissory estoppel as a matter of principle. Scottish cases, old and new, do seem to treat legal knowledge as fundamental, holding that 'no man can be barred from the assertion of a legal right by acts done in ignorance of his legal rights. ${ }^{50}$ I know of no promissory estoppel cases in which the court even inquires into this point, which would suggest that the issue is immaterial. On the other hand, the Scots requirement of legal knowledge seems generally to be presumed, and the presumption is strengthened by the rule, subject to exception, that ignorance of the law is not a good rejoinder to a plea of personal bar. ${ }^{51} \mathrm{I}$ am thus unsure to what degree this requirement distinguishes personal bar from promissory estoppel in a way that would make a difference in many decided cases, and this scepticism is reinforced by the advent of statutory bar under the Requirements of Writing (Scotland) Act 1995, which omits any knowledge requirement. $^{52}$

\footnotetext{
${ }^{49}$ See ibid at 30.

${ }^{50}$ Lauder v Millars (1859) 21 D 1353 at 1357 per Inglis LJC; see also Porteous’ Trs v Porteous 1991 SLT 129; Strathclyde Regional Council v Persimmon Homes (Scotland) Ltd, 1996 SLT 176.

51 See Reid \& Blackie, Personal Bar (n 16) at 41-42.

52 See Requirements of Writing (Scotland) Act 1995 s 1; Reid \& Blackie, Personal Bar (n 16) para 2-34.
} 
As a general matter, the Act gives many of the ideas of personal bar, and thus of promissory estoppel, statutory form insofar as they provide an exception to formal requirements. This result may be seen by considering the (simplified) facts of Smith $v$ Oliver under the 1995 Act, assuming the church could show reliance on the parishioner's promise to pay for the new roof: the promise would likely have been enforceable. ${ }^{53}$ The statute would seem to give these principles greater authority and clarity than could be achieved through sporadic development through common law; at the same time, statutory status could lead the courts to stricter application of particular language instead of judicious moulding of general principle. The statute eschews the vague 'promise' in favour of 'unilateral obligation.' The usual rule, the Act provides, is that 'the constitution of a contract, unilateral obligation or trust' need not be in writing. It then sets out exceptions, including the expected provisions about land and also 'a gratuitous unilateral obligation except an obligation undertaken in the course of business.'

At least four moves happen in these provisions. They abolish any requirement that promises be proved by writ or oath. They instead require a writing. They clarify that the formal requirement applies only to gratuitous promises outside a business context, not to any promises in the course of business and not to non-gratuitous promises outside the business context. (It may be doubted whether a unilateral obligation can be anything but gratuitous, as there is 'no counterpart obligation,, ${ }^{54}$ or even acceptance. If the promise is made in recognition of a natural or moral obligation, or is meant to repay a past debt, it might not best be characterized as gratuitous, however: donative intent—animus

\footnotetext{
${ }^{53}$ M Hogg \& H MacQueen, "Donation in Scots Law”, in M Schmidt-Kaessel (ed) Donation in Europe (forthcoming) at 9.

${ }^{54}$ H L MacQueen "Constitution and Proof of Gratuitous Obligations: A Comment on Scottish Law Commission Memorandum No. 66” 1986 SLT 1 at 2 (10 Jan 1986), sets forth his view that all promises are gratuitous essentially for this reason.
} 
donandi-is lacking. The promisor may instead intend to fulfil and discharge an obligation, imperfect though it may be. ${ }^{55}$ ) Most importantly for present purposes, the statute provides that the promise be constituted, not merely proved, in writing. This last move opens the way for exceptions to formal requirements based on the principles underlying homologation and rei interventus.

The modern statute, of course, would not leave those two common law rules in place, and it abolishes them expressly and substitutes its own formula. To simplify, where one party has materially relied, the other party may not withdraw if doing so would result in material harm. The lack of formality is forgiven. Although the statutory language is lengthy and convoluted, this Scottish statute essentially states the principle of promissory estoppel as applied to problems posed by the statute of frauds - a principle stated explicitly in $\S 139$ of the Second Restatement of Contracts. Here the point that may need qualification is that the 1995 Act requires that the reliance take place with the promisor's 'knowledge and acquiescence.' What is meant by these words is less than clear. Professors MacQueen and Thomson suggest that actual knowledge is necessary, although acquiescence is likely to be presumed. ${ }^{56}$ But we may still wonder: is the requirement

\footnotetext{
${ }^{55}$ Cf La Civ Code arts 1523-1526 (so-called donations that are sufficiently remunerative are not treated as donations), and on remuneratory donations in Scots law, see W M Gordon, "Donation”, in The Laws of Scotland: Stair Memorial Encyclopaedia vol 8 (1992) para 608. Note that an imperfect obligation, while not binding in a legal tribunal, is nevertheless binding in foro conscientice, as Stair knew, see Inst I.10.4. Professor McBryde, noting that many promises occur in a commercial context, also holds that 'not all promises are gratuitous.' McBryde (n 1) at 48 . This conclusion may be bolstered by the positive presumption, ancient and modern, against donations. 'It is a rule in law, donation non prcesumitur; and therefore, whatsoever is done, if it can receive any other construction than donation, it is constructed accordingly.' Stair, Inst I.8.2. See also infra note 187 (commercial payment adjustments that are neither donative nor onerous or synallagmatic). The difference of opinion noted here, seems of course to centre on what is meant by gratuitous, a seemingly fine point that might have broad implications for the basis of legal obligation. The issue, however, is beyond the scope of the present paper. For further discussion, see Hogg \& MacQueen (n 53); Martin Hogg, Obligations (n 35) paras 2.06-2.11.

${ }^{56}$ MacQueen \& Thomson, Contracts (n 35) para 2.49.
} 
satisfied if the reliance is foreseeable, ${ }^{57}$ perhaps even expected and desired, ${ }^{58}$ but the promisor has not been informed that it has actually taken place? There may be some work for the courts here, and it will be informative to observe the judicial reactions and whether the old stance on knowledge under rei interventus doctrine is continued. ${ }^{59}$ Certainly the promisor's knowledge and acquiescence would always be relevant to promissory estoppel, if for no other reason than the relevance of injustice. ${ }^{60}$

The clarity that might be expected of a modern statutory codification of bar with respect to formalities, however, is arguably illusory in the case of the 1995 Act. Certainly the drafting is infelicitous, as Professors MacQueen and Thomson charitably put it, and its circumlocution raises a number of technical questions of statutory interpretation that could make a real difference in the results of cases. ${ }^{61}$ Although interesting, these questions do not raise points of particular comparative importance, so they will be ignored here. In addition, while the abolition of recourse to oath raises a matter of comparative interest, promissory estoppel is only remotely relevant to the issue, if at all. ${ }^{62}$ Again, the issue is excluded here.

Finally, the Act applies its reliance principles to variations, thus bringing this analogue of promissory estoppel into interestingly familiar territory. Contract modifications have traditionally raised the very two problems in the Common Law that promissory estoppel has characteristically attacked. Because of the pre-existing duty rule-a corollary of the bargain theory of consideration-modifications often lack

\footnotetext{
${ }^{57}$ As in the formulation in Restatement (Second) of Contracts s 90.

${ }^{58}$ As in the classic promissory estoppel cases like Ricketts $v$ Scothorn 77 NW 365 (Neb 1898), and Greiner v Greiner 293 P 759 (Kan 1930).

${ }^{59}$ For the pre-statutory standard, see Danish Dairy Co v Gillespie, 1922 SC 656.

60 The principle is most familiar from the land cases like Greiner and is encapsulated in Restatement (Second) of Contracts § 129 (reliance on 'continuing assent').

${ }^{61}$ MacQueen \& Thomson, Contracts (n 35) paras 2.47-2.53.

${ }^{62}$ Cf UCC § 2-201(3).
} 
consideration and may be deprived of force for that reason. In addition, not only may the usual requirements of the statute of frauds fell the modification, but the parties may add their own statute of frauds by requiring that all contract modifications be in writing. Although these ‘no oral modification’ clauses were invalid at American Common Law, Article 2 of the Uniform Commercial Code validates them, but subjects them to an exception based on the ideas of estoppel. ${ }^{63}$ The 1995 Act thus aligns itself with American notions of promissory estoppel, although these notions are more salient in American law generally than in Louisiana in particular.

\section{MIXING BOWLS}

It may well be asked how Louisiana and Scotland got to where they are on these questions, and an attempt at an answer is an informative exercise. One of the great attractions of writing about promises in Louisiana and Scotland is the chance to observe the doctrinal mixing take place. The work in Louisiana is relatively recent-it concluded about twenty-five years ago-and the drafts of proposals and minutes of meetings are available. The relevant work in Scotland occurred centuries ago, but careful historical research and rigorous doctrinal analysis have revealed how the mixture took place. The current study provides an opportunity to put that work together and to compare it. In both places even a casual observer can see how ingredients are imported, trimmed, sliced, and mixed with local produce. Proceeding chronologically, we begin with Scotland.

\section{(1) Stair, Europe, the centuries, and the smoke ball}

\footnotetext{
63 See UCC § 2-209. See generally D V Snyder, “The Law of Contract and the Concept of Change: Public and Private Attempts to Regulate Modification, Waiver, and Estoppel” 1999 WisLRev 607.
} 
The remarkable law of Scotland on promises has excited considerable interest at least since T. B. Smith brought attention to it in the middle twentieth century, and its career since then has been no less remarkable, now being taken into the Principles of European Contract Law and the Draft Common Frame of Reference. ${ }^{64}$ As is seemingly true of all good stories in Scots law, the seventeenth-century studies of Stair are the starting place, although admittedly the account here is simplified, even as Stair himself offered a simplified analysis of a complex dispute within the civil law, canon law, and the ius commune. ${ }^{65}$

Stair treats promises in his title, 'Obligations Conventional, by Promise, Paction, and Contract.' In his scheme, the promise leads to an obligation, which is a restriction on the liberty that he regards as a man's starting point. These obligations restrict our liberty because of 'our will and consent,' and so in modern terms they might be denominated consensual obligations. ${ }^{66}$ One of the most unusual features of the Scots law of promise is that no agreement or coming together is required (so they are not conventional). The exercise of the will results in an 'engagement [that] is a diminution of freedom, constituting that power in another, whereby he may restrain, or constrain us to the doing or performing of that whereof we have given him power of exaction.' So Stair introduces his subject.

\footnotetext{
64 'A promise which is intended to be legally binding without acceptance is binding.' Principles of European Contract Law art 2:107; similarly, see Draft Common Frame of Reference for European Contract Law, bk II, arts 1:103(2), 4:301-4:303. See also T B Smith, Pollicitatio_Promise and Offer, 1958 Acta Juridica 141, reprinted in T B Smith, Studies Critical and Comparative (1962) 168 (henceforth Smith, "Studies Critical”); T B Smith, "Unilateral Promise (Pollicitation)", in A Short Commentary on the Law of Scotland (1962) ch 32.

${ }^{65}$ Stair is the primary source, as may be seen from the notes below, but the Lord Lyon's history of promise, see Sellar (n 35), contains much of the information, and the complexity of the debate within the ius commune comes through most clearly in MacQueen \& Sellar (n 35) at 358-65.

${ }^{66}$ Stair, Inst I.10.1.
} 
His next point is of keen interest to the current inquiry, for he introduces a qualification akin to estoppel or bar: 'But it is not every act of the will that raiseth an obligation, or power of exaction ... . ${ }^{67}$ Instead, he distinguishes between 'desire, resolution, and engagement,' and only the last of these gives rise to an obligation. This he holds even if there be clear proof of a resolution 'by word and writ,' and cites a case to this effect. ${ }^{68}$ So even a written resolution is not the same as a promise-a point that will resonate in a case in $2007^{69}$ —and this holding raises two questions: first, what the difference between a resolution and a promise is, and second, what happens if someone is injured by this clear resolution. The second question is answered with an exception, as it appears that Stair would find an obligation if 'the resolution be holden forth to assure others. ${ }^{70}$ This, it would seem, is related to the notion of personal bar, although not so termed, and it seems based essentially on the interests of the 'others,' as the resolution by itself is insufficient, although Stair does not require any reliance, at least explicitly.

As far as I have been able to find, Stair answers the first question with a circular definition, ${ }^{71}$ but that is not of primary interest here. The explanation of the promise certainly is, however, not just because of the significance for promissory estoppel but also because of the mixing. Stair states that 'a promise is that which is simple and pure, and hath not implied as a condition, the acceptance of another, ${ }^{, 72}$ and he thus distinguishes an obligation based on a promise from an obligation based on a contract,

\footnotetext{
${ }^{67}$ Ibid.

${ }^{68}$ Ibid I.10.2 (citing 27 Feb 1673, Kincaid contra Dickson [2 Stair 181; M 12143]).

${ }^{69}$ Countess of Cawdor v Earl of Cawdor, discussed infra notes 165-168 and accompanying text.

${ }^{70}$ Stair, Inst I.10.2.

${ }^{71} \mathrm{Ibid}$ ('the only act of the will, which is efficacious, is that whereby the will conferreth or stateth a power of exaction in another, and thereby becomes engaged to that other to perform').

${ }^{72}$ Ibid I.10.3.
} 
which 'is the deed of two, the offerer and the accepter. ${ }^{, 73}$ This distinction draws on roughly four categories of sources, depending on the categorization: natural law, canon law, civil (Roman) law, and Scots law. Stair begins by considering and rejecting Grotius’s requirement of acceptance. ${ }^{74}$ (I here categorize Grotius as a natural law treatise, though it may certainly be considered otherwise.) Unaccepted promises, Stair asserts, 'now are commonly held obligatory, the canon law having taken off the exception of the civil law, de nudo pacto.'

Here can be observed the authority of the civil law (meaning Roman law), but as updated and even superseded by canon law. The reference to canon law is not expounded, but it comes up slightly later with respect to proof. Stair explains the position of Roman rules of nudum pactum, but says, 'We shall not insist in these, because the common custom of nations hath resiled therefrom, following rather the canon law, by which every paction produceth action, et omne verbum de ore fideli cadit in debitum. ${ }^{, 75}$ The reliance on canon law is explicit, although the precise reference is obscure to the present author. ${ }^{76}$ This choice may seem less surprising given that ecclesiastical courts maintained an important role in Scotland even after the Reformation, and the Court of Session was itself largely ecclesiastical in its conception, character, and outlook. ${ }^{77}$ Stair also cites the views of Petrus Gudelinus and of Corvinus, and we here find a reference to 'the common

\footnotetext{
${ }^{73}$ Ibid I.10.2.

${ }^{74}$ Ibid I.10.3 (citing Grotius, de jure belli, lib.2.cap.II.§14).

${ }^{75}$ Ibid I.10.7 (citing C.1 \& 3 de pactis [C.2,3, 1 and 3]).

${ }^{76}$ The point here is that Stair attributes the idea to the canon law. Untutored in canon law, the present author cannot vouch for the provenance of the maxim, however, and indeed entertains some questions on the matter. Where Stair actually found the maxim could well inform understandings about historical sources of Scots law, but those inquiries will have to await another occasion. Perhaps Stair was the aphorist himself, simply giving his own "version of the canonist pacta servanda sunt.” H L MacQueen, "Good Faith in the Scots Law of Contract: An Undisclosed Principle?” in A D M Forte (ed), Good Faith in Contract and Property Law (1999) 5 at 8 n 39.

77 Sellar (n 35) at 264-266.
} 
custom of nations,' in Latin possibly rendered as ius gentium, although here probably better denominated ius commune, meaning the post-antique custom of nations rather than the ius gentium of the Roman law. To the beginnings of the law of nature, as represented by Grotius, then, we find the law of ancient Rome, the law of the medieval Church, and the custom of nations-meaning, notably, Continental nations.

As will be recalled, however, these sources were not all, for Stair also included Scots practice, represented in the paragraph on promise by case law, and later, by what he says is a statute. Three cases are marshalled to give the Scots law of promise. Further research has shown that Stair was accurately representing the contemporary law in Scotland, although the statute he had in mind is a bit vexing, ${ }^{78}$ and an examination of Hope suggests that Stair did not fully explain that Scots law had not entirely gone down the path of the canon law, at least when Hope was writing. Hope's view, while sympathetic to the canon law idea, says that the 'comone law' of Scotland differed from the canon law. ${ }^{79}$ We might thus detect a bit of advocacy in Stair-assuming no significant change in the 'comone law' between Hope and Stair-as Stair chooses his main ingredients and selects carefully among the other ones, finding the choicest bits that fit with his goals and rejecting other, less appealing bits. Also noticeably absent is the law of England. However it is considered, then, the law propounded by Stair was a gourmand mixture, drawing on sources crossing centuries and crossing the Continent (but not dipping south into England), offering a wide but select list of ingredients.

Before leaving Stair, the problem of proof needs further exploration, and here the case law is brought to bear. Promises, he says, cannot be proved by witnesses, even for

\footnotetext{
${ }^{78}$ Ibid at $260-261$.

${ }^{79}$ Ibid at 264.
} 
small amounts - unlike contracts. He suggests an exception where the promises 'are parts of bargains about moveables,' but the general rule is unyielding, and a writ would be necessary. He justifies this on Roman law grounds: just as 'the Roman law gave no action upon naked pactions, to prevent the mistakes of parties and witnesses in communings,' Scots law sought to prevent such mistakes, particularly since writing had become 'so ordinary,' and those who failed to avail themselves of 'so easy a method' could not resort to legal process. In such cases, the promise could be recognized only in the conscience of the promisor - a formulation that evokes the imperfect obligation of the natural law writers. $^{80}$

Although the mixing can be observed in the seventeenth century, its importance in modern law can be credited to the twentieth century work of T. B. Smith and what has been called the 'neo-Civilian revival' that took place after the Second World War. ${ }^{81}$ Two of Smith's works served to bring the Scots law of unilateral promise, if not into the forefront, at least out of obscurity. Part of his work has special import here because it takes on the fusion or confusion of English and Scots law on promises and contracts, particularly with respect to options and rewards. ${ }^{82}$ (I leave the stipulatio alteri to another author in this volume.) ${ }^{83}$ Possibly the leading edge on which English law worked its way into Scotland was the infectiously memorable and thus powerful case of Carlill $v$ Carbolic Smoke Ball Co. ${ }^{84}$

With that case in mind, Smith demonstrated how the unwieldy English requirements of offer and acceptance as well as consideration were brought into the Scots

\footnotetext{
${ }^{80}$ Stair, Inst I.10.4.

${ }^{81}$ MacQueen \& Sellar (n 35) at 380.

${ }^{82}$ Smith, "Studies Critical” (n 64) at 178-82.

83 \{Cross reference\}

${ }^{84}$ [1892] 2 QB 484; [1893] QB 256.
} 
law of rewards and options. ${ }^{85}$ The result of Stair's careful mixture, that is, the law of unilateral promise, seemed slowly to have been smoothed away under the successive waves of cases taking an English approach, attempting to fit promises into contracts with acceptance and consideration. ${ }^{86}$ The Scots law certainly was not washed away in this period, as the 1899 case of Morton's Trustees v Aged Christian Friend Society ${ }^{87}$ shows, but it was in rather a sorry state. Morton's Trustees brought in the law of promise when offer and acceptance was the accurate analysis for the facts, ${ }^{88}$ and it has been said that there was also an element of rei interventus. ${ }^{89}$ Other cases approached the law of promise more carefully. ${ }^{90}$ But the problems of the assimilation of Scots law in the early twentieth century were clear, with confusing consequences on common fact patterns, involving ideas like options or modifications. ${ }^{91}$

What Smith did was to illustrate the elegance of the Scottish (i.e., non-English) solution and place it into a comparative context that gave it both pedigree and gravitas. His work takes into account the great Civil Law families of French and German law and particularly addresses Roman-Dutch law and South African law. He explains where Stair's—and Scotland's—solution fits among those respectable traditions, and he demonstrates the superior doctrinal simplicity of a Scottish analysis of the problems

\footnotetext{
${ }^{85}$ The terminology is troubling here, as many of the 'reward' cases are about undertakings by publishers and their insurers to pay anyone — or his estate—if he should die in a railway accident while carrying a particular newspaper or diary. Similarly, an 'option' sounds like it is short for an 'option contract,' but only a price said to be good for a set period is meant. Writing in English brings in English connotations, yet using Scottish legal terminology is too narrow given the mixing involved. This very failure of language to fit may be an interesting point itself about the issues of mixed jurisdictions, from the standpoint of linguistics or linguistic anthropology.

${ }^{86}$ Law v Newnes [1894] 21 R 1027; Hunter v Hunter [1904] 7 F 136; Hunter v General Accident, etc., Corp 1909 SC 344, 1909 SC (HL) 30.

${ }^{87}$ [1899] 2 F 82.

${ }^{88}$ E.g. McBryde, Contracts (n 35) para 2-24.

${ }^{89}$ See Wick Harbour Trs $v$ The Admiralty [1921] 2 SLT 109 at 112 per Lord Sands (OH).

${ }^{90}$ See ibid.

${ }^{91}$ A \& G Paterson v Highland Ry 1927 SC (HL) 32.
} 
posed by the cases. This is work of mixture and comparison as well as scholarship and advocacy, and judging from the following century, it seems to have been effective.

Perhaps the best way to appreciate Smith's success is to look at the doctrine now. Professor MacQueen followed Smith a generation or so later with a similar analysis, noting an English case in which trustees had committed to accepting the highest bid ${ }^{92}$ and showing again how Smith's Scottish treatment of the smoke ball case, using the law of unilateral promise, produced the right result with a simpler and more accurate legal characterization of the facts. ${ }^{93}$ Admittedly the necessity of Professor MacQueen’s article shows that Smith was not complete in his success; while several cases took the Scottish road to enforcing options as unilateral obligations, ${ }^{94}$ some (notably Professor Walker) seemed instead to follow 'the approach of English law. ${ }^{95}$ The echoes of Smith and the smoke ball explanation continue, appearing still in Professor McBryde’s standard work. ${ }^{96}$ The reverberation evidences what may be unavoidable for a mixed jurisdiction like Scotland or Louisiana: a distinctiveness in the smaller jurisdictions (Scotland and Louisiana) that is defined by differing from the dominant jurisdiction (England and the United States).

So Scotland came to have its doctrine of the unilateral promise. It was a simple accomplishment in that it seems to owe everything to Stair, and his authority and his clarity. But it was a complex concatenation that led to this simple result. Hope and Stair provide conflicting perspectives on Scots law. Hope inclined toward the canon law, thus

\footnotetext{
${ }^{92}$ Harvela Investments v Royal Trust Co. of Canada [1984] 2 All ER 65; [1985] 1 All ER 261.

${ }^{93}$ H MacQueen, “Offers, Promises and Options” SLT (Articles) 187 (21 June 1985).

${ }^{94}$ Sichi v Biagi 1946 SN 66; Scott v Morrison 1979 SLT (Notes) 65; Stone v MacDonald 1979 SLT 288; Gloag, Contract 166.

${ }^{95}$ MacQueen (n 93) at 189. Professor Walker was apparently following Hamilton $v$ Lochrane (1899) $1 \mathrm{~F}$ 478, a case from the period where Smith had found the most confusion.

${ }^{96}$ McBryde, Contracts 3d edn (2007) paras 2-05 and 2-27. Compare the 2d edn (2002) and McBryde (n 1) at 63-64.
} 
giving Scots law a stir. A bit later, Stair drew on natural law and canon law and civil law-in short, the complex of the ius commune-and found a protection for a unilateral promise. The unique flavour was diluted later, by further mixing and further imports from English law, until Smith and his followers were able to write the doctrine that recited a more purely Scottish—or more accurately, a less English—rule, and returned to Stair's fold.

\section{(2) Codification in Louisiana}

Some of the most interesting mixing to be observed in Louisiana occurs a few centuries after Stair, and the best view in this particular Louisiana cooking show is to be seen through the lens of the Civil Code revision. ${ }^{97}$ This modern recipe seems more complex than the Scottish version as the many chefs in the kitchen were aiming at a re-mix. The Council of the Louisiana State Law Institute wanted to remove consideration from Louisiana obligations law and also wanted to add promissory estoppel. This desire was made explicit in so many words when the Council 'instructed the reporter to draft an article that would make it quite clear that "cause" is not "consideration" in the Common Law sense, and, further, to introduce a concept analogous to “detrimental reliance” or “promissory estoppel.”,98 The developments with respect to cause and consideration have been summarized above, but here the introduction of promissory estoppel deserves specific examination.

\footnotetext{
97 This section draws on Snyder (n 4) at 706-23.

${ }^{98}$ Louisiana State Law Institute, Revision of the Louisiana Civil Code of 1870, Book III—Obligations Revision-Cause, at 3 (20 Apr 1979) (prepared for Meeting of the Committee, 20 Apr 1979, but handdated “3-13-79” suggesting a date of 13 March) (Saúl Litvinoff, Reporter) (henceforth Apr 1979 Draft).
} 
The model for promissory estoppel, patently, was the Restatement (Second) of Contracts § 90. The earliest available draft defines cause, distinguishes it from consideration, and provides for promissory estoppel. The draft reproduces $\S 90$ of the Restatement below the proposed Code language, along with previous Code articles defining cause. The Common Law doctrine of promissory estoppel was being grafted onto the Code at the same time that consideration was being excised. The irony is doublefaced: not only are Common Law notions defining cause, positively and negatively, but promissory estoppel is being imported at the same time that the chief doctrine that made it necessary is being deported. If this were not enough, the reporter was further 'instructed to make detrimental reliance compatible with cause.' 99 This he endeavoured to do by a bit of sleight of hand: instead of having cause be the 'motive' for making a promise, as in article 1896 of the Code of 1870 (leaving out the troublesome mention of consideration), one might say the cause is the reason for making the promise. Then one might say that '[c]ause is the reason that makes an obligation enforceable.'

Hardly a significant change, it would seem at first, except that the sleight of hand would turn cause around entirely. Cause began as the motive of the promisor. The cause of a contract, then, may be illegal, in which case the promise would not be enforceable, but the promise would still have a cause. In the proposed formulation, if the promise is supported by cause, it is for that very reason enforceable, by definition. Cause has been not only turned around, then, but made to serve the same function as consideration. To be clear, it did not employ the same test as consideration—no bargain was to be required— but the function of the doctrine was to be the same. At Common Law, if there is consideration the promise is enforceable, and otherwise not. Under the proposed

\footnotetext{
${ }^{99}$ Ibid at 2-3.
} 
formulation, if there is cause, the promise is enforceable, and otherwise not. This proposition is a far cry from the original scheme, and while Civilian in its adherence to a cause not identical to bargain, it is being driven by concerns emanating from the Common Law.

The mixing is also apparent in how the introduction of promissory estoppel is justified. The arguments in favour of the doctrine are put three ways. Promissory estoppel, the reporter says, is consonant with principles in the existing Code, including its Napoleonic general article on delictual obligation: 'Every act whatever of man that causes damage to another obliges him by whose fault it happened to repair it. ${ }^{, 100} \mathrm{He}$ also says that promissory estoppel has been recognized in the case law. This proposition was a bit difficult in light of the Supreme Court of Louisiana decision in Ducote v Oden, as mentioned above, but the reporter identified the undercurrent of cases that applied the principle sub rosa both before and after Ducote.

Perhaps the most remarkable argument is the last: that promissory estoppel is in essence a Civil Law doctrine anyway. It is likened to delictual and quasi-delictual obligations in the Civil Law, and it is linked particularly to culpa in contrahendo, the primarily German doctrine that provides a remedy against one whose fault in the contracting process damages the other party. ${ }^{101}$ It is also linked to 'the binding force of a unilateral declaration of will, ${ }^{102}$ the very same idea observed in Scotland, and most clearly in Stair. The crowning glory, though, goes to the assertion that estoppel is

\footnotetext{
${ }^{100}$ The quotation comes from article 2315 of the Code of 1870, although this paragraph remains essentially unchanged in the current Code. It is the same (except for a typographical error) as article 1382 of the Code Napoléon ('Tout fait quelconque de l'homme, qui cause à autrui un dommage, oblige celui par la faute duquel il est arrivé, à le réparer.'). The April 1979 Draft at 2 cites both this article and, more obscurely, article 1791.

${ }^{101}$ The doctrine is explained, with citations to the literature, in Snyder (n 4) at 703-06.

${ }^{102}$ Apr 1979 Draft (n 98) at 6-7.
} 
descended from the Roman law doctrine of venire contra factum proprium. ${ }^{103}$ The assertion that promissory estoppel is not a Common Law invention after all, and is instead Roman and thus quintessentially of the Civil Law, is no less remarkable for its dubiety. Venire contra factum proprium is more generally viewed as being based on facts rather than executory promises, and is therefore closer to equitable estoppel (i.e., estoppel in pais) rather than promissory estoppel. Moreover, venire factum proprium is probably better attributed to the ius commune, and perhaps Bartolus originally, rather than Rome, as earlier research has shown. ${ }^{104}$ But these are scholastic points. The impetus came from the American Common Law and the Restatement. The revision draft reproduces section 90, not a text from the Digest or from Bartolus, neither of which is very clearly about promissory estoppel anyway.

So we see mixing, and machinations, in three ways. First, the very fact that promissory estoppel is being introduced shows a mixture, as the rule of the American Common Law is taken from the Restatement and paraphrased into the Civil Code. Second, the juxtaposition of Common Law and Civil Law thinking drove efforts (ultimately unsuccessful) to define cause in a way that would have been consonant with promissory estoppel and that would have made cause serve the same function as consideration, albeit not requiring a bargain. Third, the attempt to justify promissory estoppel as a doctrine of Civil Law, and even Roman law, shows the kind of Civilian

\footnotetext{
${ }^{103}$ Ibid at 7 ('It is worthwhile to mention that, after all, neither estoppel in pais nor promissory estoppel are common law inventions. The notion of estoppel descends directly from the Roman venire contra factum proprium.') (citing Jose Puig Brutau, Estudios de Derecho Comparado (1951) 97).

${ }^{104}$ The key texts are probably D 12.4.5.pr. (Ulpian, Diputationum 2), 4.3.34 (Ad Sabinum 42), 19.5.16.1 (Ad Sabinum 22), 17.1.15 (Paul, Ad Sabinum 2); see also Gai Inst 3.160; Matthias Schwaibold, Brocardica (1985) 43 (under 'Neminem debere venire contra factum suum et si non valeat quod fecit'). The quotation from Bartolus is 'non potest quis venire contra factum suum ad sui commodum etiam ex persona alterius.' Bartolus, Commentaria ad D 12.6.2. The texts are parsed and further sources are cited in Snyder (n 4) at 712-13 n 100.
} 
striving that can be expected only when Common Law thinking seems uncomfortablyeven threateningly—close.

\section{PROMISSORY ESTOPPEL JOBS}

Discussing and comparing doctrines in the abstract can lead to a disembodied logic, as well as to errors born of finding cognate doctrines that sound similar but whose use is different. One way to check that the doctrines under examination bear comparison is to consider what jobs they do. ${ }^{105}$ The constraints of a micro-comparison and of space prevent a thorough examination, but an overview is a helpful validating device.

Promissory estoppel in Louisiana, an earlier study suggested, worked in many of the same sorts of jobs associated with promissory estoppel in the rest of the United States, ${ }^{106}$ and this situation continues under current case law. Subcontractor bids led to some of the classic cases of American promissory estoppel, ${ }^{107}$ and Louisiana has seen its share of them too. These cases are usually about problems of option contracts, irrevocable offers, and the like. The more general problem of so-called 'precontractual' liability can itself be a source for promissory estoppel claims, and again Louisiana has seen its share, including disputes about options. ${ }^{108}$ The cases in Louisiana, as in the

\footnotetext{
${ }^{105}$ I am indebted to Karl Llewellyn’s thinking about law-jobs. See generally K N Llewellyn, “The Normative, the Legal, and the Law-Jobs" 49 YaleLJ 1355 (1940).

${ }^{106}$ The cases for the first dozen years of promissory estoppel in the Civil Code are collected and classified in Snyder (n 4) at 734-47.

107 James Baird Co v Gimbel Bros 64 F2d 344 (2d Cir 1933); Drennan v Star Paving Co 333 P2d 757 (Cal 1958).

${ }^{108}$ For cases involving alleged potential precontractual liability issues, see Suire v Lafayette City-Parish Consol Govt, 907 So2d 37 (La 2005); Baker v LSU Health Scis Ctr, Inst of Professional Education 889 So2d 1178 (La Ct App 2004); Hibernia Nat'l Bank v Antonini 862 So2d 331 (La Ct App 2003) (loan case, claimed promise of permanent funding); Holt v Bethany Land Co 843 So2d 606 (La Ct App 2003) (option holder was using the land); Magic Moments Pizza, Inc v Louisiana Restaurant Assn 819 So2d 1146 (La Ct App 2002) (insurance coverage through detrimental reliance); Haring v Stinson 756 So2d 1201 (La Ct App 2000). See also Gangi Seafood, Inc v ADT Security Services 2005 US App LEXIS 4 (5th Cir 2005) (alarm service); Rogers v Brooks, 122 Fed Appx 729 (5th Cir 2004); Becnel v Whirley Indus 2003 US Dist LEXIS
} 
United States more widely, often revolve around claims that insurers have granted insurance in some provisional but binding way (at least temporarily), or that a lender has committed to making a loan. The reporters are filled with such cases, and again Louisiana has been no exception, at least until recently. There have now been legislative efforts to quash this effect in Louisiana, ${ }^{109}$ and since the Louisiana Supreme Court has made clear that it will broadly and strictly enforce this special statute of frauds for credit agreements, ${ }^{110}$ the loan cases may dissipate. One prominent job for promissory estoppel would thus be eliminated, but it is nevertheless a limited exception.

In addition, promissory estoppel claims are sometimes asserted instead of contract claims. When this phenomenon was perceived it excited much scholarly comment in the United States as it seemed to bolster the earlier claim that contract was dead: not only because promissory estoppel had killed consideration, but because promissory estoppel was a more viable general cause of action than the technically constrained contract action. For some time this scholarship was so generally accepted that it was referred to as the 'new consensus' on promissory estoppel. Further studies, however, have shown that these effects appeared exaggerated, primarily because promissory estoppel claims rarely

21575 (D La 2003) (precontractual liability and confidentiality); Starco Meats, Inc v Bryan Foods, Inc 2003 US Dist LEXIS 4452 (D La 2003); Jobe v ATR Mktg, Inc 1998 US Dist LEXIS 18171 (D La 1998) (option). Cases involving problems of agency or mandate might also be put in this category, or perhaps they deserve a classification of their own. On these issues, see Freeman Decorating Co $v$ Encuentro Las Americas Trade Corp 2005 US Dist LEXIS 18313 (D La 2005); Dan Rhodes Enters v City of Lake Charles, 857 So2d 1256 (La Ct App 2003).

${ }^{109}$ Since 1989, credit agreements must be stated in signed writings. La Rev Stat Ann § 6:1122, per 1989 La. Acts no. 531, § 1. Although not relevant to the point in the text, surely it must be remarked that the new statute requires a written expression of 'consideration'!

${ }^{110}$ Jesco Constr Corp v Nationsbank Corp 830 So2d 989 at 992 (La 2002) (holding that the writing requirement for credit agreements bars all actions, including detrimental reliance, based on unwritten loan agreements). 
win. More than one study has now found that the courts are generally unsympathetic to promissory estoppel, and that contract is a considerably firmer ground for recovery. ${ }^{111}$ Again, Louisiana is susceptible of similar descriptions. A number of cases asserting promissory estoppel claims could be put into the 'completed contract' category, and this gives rise to the idea that promissory estoppel is supplanting contract, or other more specific rules. Sometimes, indeed, this observation is accurate, ${ }^{112}$ and sometimes a detrimental reliance claim can even seem to displace or at least supplement a contract. ${ }^{113}$ Because the courts can be so stringent in their approach to promissory estoppel, though, such claims often fail. For this primary reason the later studies have found contract very much alive, promissory estoppel being the kind of last resort it was designed to be, and some Louisiana cases suggest this mindset. ${ }^{114}$ While there are certainly cases that bring promissory estoppel into the realm of completed synallagmatic contracts, ${ }^{115}$ and thus may

\footnotetext{
${ }^{111}$ See S W DeLong, "The New Requirement of Enforcement Reliance in Commercial Promissory Estoppel: Section 90 as Catch-22" 1997 WisLRev 943; R A Hillman, "Questioning the 'New Consensus' on Promissory Estoppel: An Empirical and Theoretical Study" (1998) 98 ColumLRev 580. The main articles forming the brief 'new consensus,' which had been proclaimed in R E Barnett, "The Death of Reliance” (1996) 46 JLegalEduc 518 at 522 were D A Farber \& J H Matheson, "Beyond Promissory Estoppel: Contract Law and the 'Invisible Handshake”" (1985) 52 UChiLRev 903, and E Yorio \& S Thel, "The Promissory Basis of Section 90" (1991) 101 YaleLJ 111 at 129.

${ }^{112}$ Woodard v Felts 573 So2d 1312 at 1315-16 (La Ct App 2d Cir 1991), and Kethley v Draughon Business College, Inc 535 So2d 502 at 506-07 (La Ct App 2d Cir 1988), use article 1967 instead of the specifically applicable article 1952 on determining damages when consent is vitiated by error.

${ }^{113}$ See Water Craft Mgmt LLC v Mercury Marine 361 FSupp2d 518 (D La 2004) (competitor/franchise); Comprehensive Addiction Programs v Mendoza 50 FSupp2d 581 (D La 1999) (sales contract that did not close for lack of a loan); see also Industrias Magromer Cueros y Pieles SA v Louisiana Bayou Furs, 293 F3d 912 (5th Cir 2002) (finding twin contract and detrimental reliance claims based on the same operative facts).

${ }^{114}$ Condrey v SunTrust Bank of Ga, 429 F3d 556, 565-66 (5th Cir 2005) (where parol evidence is inadmissible to vary a contract, detrimental reliance doctrine is inapplicable and does not change the result (citing Omnitech Intl v Clorox Co 11 F3d 1316 at 1330 (5th Cir 1994)); Drs Bethea, Moustoukas and Weaver LLC v St Paul Guardian Ins Co 376 F3d 399 (5th Cir 2004) (insurance contract: no detrimental reliance possible within the scope of integrated contract); McDermott Intl $v$ Indus Risk Insurers, 2003 US Dist LEXIS 22286, concl. of law paras 22-24 (D La 2003) (insurance contract: sophisticated party should not rely on assertions outside the contract); Ark Entertainment, LLC v C J Gayfer \& Co, 2000 US Dist LEXIS 3867 (D La 2000) (real contract precludes detrimental reliance); In re Horn 827 So2d 1241 (La Ct App 2002) (court in the end uses public records doctrine rather than detrimental reliance).

${ }^{115}$ See Shreveport Plaza, LLC v Dollar Tree Stores, Inc 196 Fed Appx 320 (5th Cir 2006), in addition to the cases cited above (n 113).
} 
be seen to undermine the law of contract, there are also cases that hold that where there is a synallagmatic contract, that contract provides the rights of the parties rather than alleged promises and detrimental reliance. ${ }^{116}$ Along the same lines, courts seem unlikely to find reasonable reliance when the alleged promisor has not made a promise that rises to the level ordinarily associated with a contract or guarantee. ${ }^{117}$

In the completed bargain cases, sometimes a lack of formalities is the cause for the move into promissory estoppel. At first the Louisiana courts appeared reluctant, and they seemed poised to join the states that resisted the general rule, encapsulated in the special section of the Restatement (§ 139, as opposed to the usual § 90), that promissory estoppel could defeat a defence under the statute of frauds. More recent Louisiana cases point in the other direction, however, and several have followed (or indicated that they would follow in appropriate circumstances) the general rule that promissory estoppel under article 1967 can trump a writing requirement. The strength of these holdings is uncertain, however, as the cases I have found all arose in securities transactions; ${ }^{118}$ while there had been an applicable writing requirement at the time that the operative events occurred, the writing requirement had been abolished by the time that the cases were decided. (As an aside, I cannot help but note that the statute of frauds involved came from Article 8 of the Uniform Commercial Code, which was revised effective $1996 .{ }^{119}$ Louisiana has adopted much of the UCC, which is itself a sign of mixture, and the

\footnotetext{
${ }^{116}$ Condrey, 429 F3d at 565-66; Drs Bethea 376 F3d 399 (integrated contract, therefore no detrimental reliance possible within scope of contract); Ark Entertainment 2000 U.S. Dist. LEXIS 3867 (real contract precludes detrimental reliance).

${ }^{117}$ Miller v Loyola Univ of New Orleans 829 So2d 1057 at 1062 (La Ct App 2002).

${ }^{118}$ Rhoads v Quicksilver Brokers, Ltd 801 So2d 1284 at 1289 (La Ct App 2001); Dugas v Guillory, 719 So2d 719 at 726 (La Ct App 1998); cf Cenac v Hart, 741 So2d 690 at 695 (La Ct App 1999) (not applying promissory estoppel exception because it had not yet become effective).

${ }^{119}$ La Rev Stat Ann § 10:8-319 (repealed effective 1 Jan 1996) had provided a statute of frauds for securities transactions, but it was abolished by revised § 10:8-311. See Rhoads, 801 So2d at 1289.
} 
bringing together of promissory estoppel, from the Restatement via the Civil Code, to the statute of frauds requirement, and its later abolition, through work of a nationwide uniform law process, is testament to the mixing that continues to occur.) The strict enforcement of the new writing requirements for loan agreements should also be recalled. $^{120}$

The main qualification when Louisiana is compared to the American Common Law is the area of family promises and gifts. These cases arguably gave rise to the doctrine in the first place, but Louisiana refused to follow. Here, after all, Louisiana has retained its Civil Law authentic act as a way of making an enforceable promise to make a gift-a legal device that the American Common Law lost when the seal fell into desuetude. Nevertheless, this part of the legal field has proved a fertile breeding ground for promissory estoppel claims in Louisiana, although they have been unsuccessful. ${ }^{121}$

Just as article 1967 has taken on the promissory estoppel jobs in Louisiana, the Scottish authorities suggest that a combination of the doctrines of promise and bar serves the same functions in Scotland. Since Smith, Professor MacQueen has probably done as much as anyone to promote the use of promise, and he has suggested several jobs for it. Following Smith, of course, he suggests its use in reward cases. More practically, he has suggested its employment in gratuitous promises, both with families or charities and with commercial promises. He has in mind a variety of commercial transactions that would fit well within the scheme of promissory estoppel jobs set out above. With respect to the gratuitous commercial promises, for example, he suggests a hypothetical (reminiscent of

\footnotetext{
120 Jesco Constr, 830 So2d at 992.

${ }^{121}$ In addition to cases cited in my earlier assessment, see Moncrief $v$ Succn of Armstrong 939 So2d 714 (La Ct App 2006); Crosby v Stinson, 766 So2d 615 (La Ct App 2000).
} 
A. \& G. Paterson v Highland Railway, ${ }^{122}$ about which Smith had also written) in which a lessor agrees to lower the rent but only during the time the tenant is experiencing financial difficulties. The hypothetical also echoes some of the estoppel-based contract readjustments that I have classified in the ‘completed bargain’ category of Louisiana cases. $^{123}$

Of course much of the use of the doctrine is suggested with irrevocable offers and options, ${ }^{124}$ particularly where advertising is involved (e.g., 'lowest tender accepted' or 'first offer over $£ Y$ secures’). ${ }^{125}$ More broadly, in this category of precontractual liability, MacQueen discusses a variety of cases that would fit well with the Louisiana case law. He notes the problems that tend to arise in large construction contracts, particularly when public bidding, final negotiation, and subcontract arrangement are involved. Frequently 'letters of intent' are used in this context in the United Kingdom, and while that is not the typical practice in the United States as far as I know, the problems generated by the complex undertakings and the need for preparation before the general contract is final is the perfect ground for the use of promise. ${ }^{126}$ Scottish law, as Professor MacQueen sees it at least, and Louisiana law would appear to have a close fit in this regard. In the postcontractual context, guarantees made after the buyer has purchased the goods might best be analyzed under a promissory rubric. ${ }^{127}$

On the other hand, there are two transactions suggested by Professor MacQueen that do not fit with Louisiana cases. One is the potential role of promise in explaining the

122 1927 SC (HL) 32. Central London Property Trust Ltd v High Trees House, Ltd [1947] K.B. 130 (1946) also comes to mind.

${ }^{123}$ Compare Shreveport Plaza, LLC v Dollar Tree Stores, Inc 196 Fed Appx 320 (5th Cir 2006).

124 These examples come from MacQueen \& Thomson, Contracts (n 35) para 2.61.

125 MacQueen (n 54) at 4.

${ }^{126}$ Ibid at 3. This assumes that the letter of intent indicates a promise, i.e., a commitment to be bound, as opposed to a mere expression of a future plan. See Hogg, Obligations (n 35) para 2.74.

${ }^{127}$ Hogg, Obligations (n 35) para 2.84, which lists a number of potential jobs for promise. 
enforceability of bankers' letters of credit and the like. The Scots law of promise has been suggested as an appropriate avenue for the analysis of these undertakings, which are often unaccepted and whose enforceability has presented a doctrinal difficulty, ${ }^{128}$ if not a practical one (as there are no Scottish cases on the issue). In the United States these issues have been governed by statute for about fifty years, since Article 5 of the Uniform Commercial Code came into widespread use. Louisiana has adopted Article 5, evidence again of mixing in the contractual and commercial law of Louisiana, and thus the enforceability of letters of credit is not a question. To the extent other questions arise about similar instruments, Louisiana also has enacted Articles 3 and 4 of the UCC on negotiable instruments and bank deposits, and again enforceability does not raise troubling issues. Professor MacQueen’s other suggestion that does not fit with Louisiana (and American) promissory estoppel jobs is the analysis of requirements contracts. But Professor MacQueen does not press this suggestion with great vigour. ${ }^{129}$

Other commercial contexts have proved ripe for analysis along the lines of promise. The facts of Krupp Uhde GmbH v Weir Westgarth Ltd. ${ }^{130}$ suggest one: large contracts often necessitate not only readjustments between the parties, requiring the kind of modifications already mentioned, but also adjustments with others. Once the fact of lending is brought into the analysis the possibilities become obvious, as one of the parties may need to obtain additional financing or may wish to refinance. Because of the demands of that party’s lender, relatively minor but crucial readjustments may be needed, as with payment instructions: a subcontractor’s lender may well insist that the general

\footnotetext{
${ }^{128}$ MacQueen (n 54) at 3.

129 Ibid at 4.

${ }^{130}$ Per Lord Eassie (OH) 31 May 2002. Note a similar Louisiana case, Boyte $v$ Wooten, 2006 US Dist LEXIS 45098, at*12-*16 (D La 2006) (reliance possible on letter regarding payments).
} 
contractor pay the lender directly instead of relying on the subcontractor to receive payment and then forward the money to the lender in repayment of the loan. Although the matter may appear technical, a binding undertaking from the general contractor to pay the lender directly can make the lender considerably more secure, and the failure of the general contractor to comply with its undertaking could be the difference between the lender being repaid in the millions or instead getting nothing at all.

The law of promise can work here, as was suggested by counsel in the case, although the court eventually decided that assignation of the payment right was a better interpretation of the transaction. In that case, I would suggest, Lord Eassie was wise for several reasons, not all of which are discussed in the opinion. The real question was whether the lender was entitled to full payment or instead only the payment due to the subcontractor after deductions were made because of problems in the subcontractor's performance. Although the issue was discussed thoroughly, Lord Eassie did not seem to suffer much doubt about the real issue: of course the lender would only get what the subcontractor itself was entitled to receive. The more interesting point here is the legal device Lord Eassie chose.

It would have been perfectly feasible to find a promise, but to interpret the promise as a commitment to pay the lender only that which was due the subcontractor. Assignation of what payment right the subcontractor had, however, not only achieves the same result but could have the added benefit of giving the lender the better security that it seemed to want. A mere promise to pay $L$ what is due to $S$ arguably keeps the payment right in $S$, while an assignation of $S$ 's payment right to $L$ may shift the property in the payment right from $S$ to $L$. In that case, should $S$ go bankrupt-the very possibility this 
arrangement contemplates $-L$ will have better grounds to argue that the payment should still be made to $L$ and is not a right that is part of $S$ 's bankruptcy estate, to be split among creditors. The parties might thus achieve their undoubted goal of bankruptcy remoteness. Krupp Uhde, then, is something of a parable about the law of promise: the doctrine is potentially so broad that it might be used beyond the bailiwick in which it works best. Other commercial contexts, however, would be better suited to promise. In American commercial practice, for example, the work (usually called ‘due diligence’) before a merger often requires the parties to obtain consent from the contractual partners of the merging parties, assuring that the merged entities will have the benefit of those preexisting contracts. The lawyers set about obtaining what are called ‘estoppel letters' from all of the key contracting partners, who promise in those letters not to object to the merger, and who perhaps consent to the assignment of the contract. If relied on, these letters can give rise to promissory estoppel, and lawyers treat them as enforceable. Estoppel, however, requires reliance, which could be difficult to prove to a court with a sceptical view (a frequent occurrence, as discussed elsewhere in this chapter). Would the parties really have foregone the merger in the absence of the estoppel letter? Often it may be shown that the merger went forward without letters from some contracting parties. Were this situation to arise in Louisiana, as it certainly does, the position if the matter were to go to litigation would be far from certain given the lack of demonstrable reliance. The Scots law of promise offers a considerably better analysis.

So far the exploration of jobs in Scots law has focused on the law of promise, but personal bar or its allied doctrines is also crucial. For centuries gratuitous promises had to be proved by writ or oath, and as has been seen, formal requirements often lead to a 
need — or desire — for an exception along the lines of promissory estoppel. Since 1995, the matter has become clearer (which is not to say clear) under the Requirement of Writing (Scotland) Act. The need for writ or oath is outright abolished for business promises, even though they may be gratuitous. The Law Revision Commission thought business promises, though possibly gratuitous, were likely to be 'very far from being rash or impulsive gestures, ${ }^{, 131}$ and Professor MacQueen, perhaps the principal proponent of the business exception, suggests that there ought not to be 'formal impediments to commercial activity. ${ }^{, 132}$ As a business promise might be found in many contexts, as with payments involved in home improvements, ${ }^{133}$ this exception may prove wide-ranging. And a reliance based exception is generally available, as discussed above, for other promises. It would seem, then, at least in theory, that the laws of promise and bar do the promissory estoppel jobs in Scotland, with some qualifications, in much the same way that article 1967 works in Louisiana.

The case law in Scotland is considerably thinner than in Louisiana, but the cases I have found in the last fifty years (with occasional reference to the older cases) suggest that promise and bar are doing promissory estoppel jobs similar to those in Louisiana. Many fall into the category I have called the cusp of contract (preferring that phrase to the more precise but less accurate 'precontractual' liability). The relatively recent case of J. W. Soils (Suppliers) Ltd $v$ Corbett ${ }^{134}$ involves an alleged promise to pay for expenses incurred as the parties considered a real estate development that would turn Rowallan

\footnotetext{
${ }^{131}$ Report on Requirements of Writing (Scot Law Com No 112, 1988) paras 2.23-2.24.

132 Hogg \& MacQueen (n 53) at 9.

${ }^{133}$ Morrison v Leckie, 2005 GWD 40-734 (Paisley Sh Ct) per Sheriff M P Anderson. I have relied on a case summary and have not seen the judgement. To the extent courts take the view of the Morrison decision, the idea of business promises may need rethinking. Compare the narrow view evinced by Hogg, Obligations (n 35) para 2.22 .

${ }^{134}$ Per Lord Cameron of Lochbroom (OH) 12 Sept 1991, available on Lexis; 1991 GWD 32-1891; 1991 CLYB 4533.
} 
Castle into a hotel and leisure centre. Stone $v$ Macdonald ${ }^{135}$ is about an option problem, and although it may be a contract case rather than a case of promise (there is some conflict here), ${ }^{136}$ it was at least founded on a case of promise. ${ }^{137}$ Other option cases include Miller Homes Ltd v Frame ${ }^{138}$ and a sheriff court case in which the promised option had prescribed. ${ }^{139}$ Mason v A. \& R. Robertson \& Black involves efforts to close a sale where the contract was already agreed by missives; in that case, the alleged promise came from a third party, the solicitor, who undertook to take care of the transaction should the parties go forward. ${ }^{140}$ But while the cases and arguments can be found, the courts are notoriously careful about finding a promise too easily. ${ }^{141}$ If the parties contemplate a transaction like a sale, which involves bilateral rather than unilateral obligation, the courts generally expect to see offer and acceptance and are unlikely to find a unilateral promise. ${ }^{142}$

\footnotetext{
1351979 SC 363 per Ross LJC.

${ }^{136}$ Sellar (n 35) at 278 and McBryde, Contracts (n 35) para 2-04 treat it as a promise.

${ }^{137}$ Ross LJC, who decided Stone $v$ Macdonald, later characterizes it as a contracts case, albeit founded on a case of promise. See Chapman v Aberdeen Construction Group Plc 1993 SLT 1205 at 1213 per Ross LJC (Sichi $v$ Biagi being the case of promise on which Stone $v$ Macdonald was based). Note that distinguishing promises from contracts in some of these cases is difficult as it implicates the question-whose answer is unclear - whether a promise, if accepted, can become a contract. See McBryde, Contracts (n 35) at 28-29. Another option case implicating ideas of promise, according to Hogg, Obligations (n 35) para 2.63 is McCall's Entertainments (Ayr) Ltd v South Ayrshire Council 1998 SLT 1403 OH.

${ }^{138} 2002$ SLT 459 para 14 per Lord Hamilton.

${ }^{139}$ Smith v Stuart 2004 SLT (Sh Ct) 2 per Sheriff D J Cusine.

1401993 SLT 773 at 778 per Lord Cameron; see also Digby Brown \& Co. v Lyall 1995 SLT 932. Uniroyal Ltd v Miller \& Co Ltd 1985 SLT $101 \mathrm{OH}$, might also be mentioned here; it involves the problem of a construction contract and preparations for it. A letter of intent that had been issued might have been understood within the doctrine of promise, but the court does not discuss the doctrine at all, and indeed, such a letter of intent may also in appropriate circumstances be understood instead as a contract (accepted when the builder commences work) rather than a promise. See Robertson Group (Construction) Ltd $v$ Amey-Miller (Edinbuirgh) Joint Venture [2005] CSOH 60 affd [2005] CSIH 89.

${ }^{141}$ McBryde, Contracts 2d edn (2001) (n 35) para 2.04 notes, 'In recent years there have been only three known cases which have been decided on the basis of an alleged promise' (citing Bathgate $v$ Rosie 1976 SLT (Sh Ct) 16; Stone v MacDonald 1979 SC 363; J W Soils (Suppliers) Ltd v Corbett 1991 GWD 321891.

${ }^{142}$ See the opinion of the Lord Ordinary in Anderson v Anderson, 1961 SC 59; Haldane $v$ Watson 1972 SLT 8 (Aberdeen Sh Ct) per Sheriff-Substitute Hamilton on 9 Sept 1970.
} 
Similarly, most of the relevant cases of statutory bar fall into the 'cusp of contract' category, reflecting deals that are partially but not wholly completed. Advice Centre for Mortgages v McNicoll involves a lease in which the parties had agreed to possession, term, and rent, and the tenants allegedly even moved in, paid rent, and improved the property. The court found that the parties regarded a purchase option as significant, however, and since they had failed to reach agreement on that point, there was no agreement that could give rise to bar. ${ }^{143}$ With respect to the parties' failure to comply with the necessary formalities - the promissory estoppel exception to the statute of frauds, in American terms - the court cast an unsympathetic eye. 'If parties do not adhere to the very simple requirements [of writing] that are now prescribed, they have only themselves to blame. ${ }^{, 144}$ Another cusp-of-contract case, Park Lane Developments (Glasgow Harbour) Ltd. v Jesner involved an alleged agreement about conveying a parking place. The buyer seemed to think he was getting a conveyance outright, but the developer offered only undivided common ownership, which the buyer (after considerable delay) rejected. A further recent case was, like so many of the promise cases, about an option. ${ }^{145}$ All of these cases suggest that arguments about statutory bar are being pressed-not necessarily successfully—in much the same context in Scotland as in Louisiana.

In the completed contract category, a distinction between the Scottish and Louisiana law should be noted. In Louisiana, because of concern about the reliability and therefore the primacy of the contract, some courts have turned away promissory estoppel

\footnotetext{
143 [2006] CSOH 58, 2006 SLT 591 per Lord Drummond Young.

144 Ibid para 16.

145 Ben Cleuch Estates Ltd v Scottish Enterprise [2006] CSOH 35. The case is discussed in more detail below.
} 
claims. This holding is made possible by the reliance element of promissory estoppel in Louisiana; a court can well hold that relying on promises not contained in the contract (or in $a$ contract, as in Miller $v$ Loyola University) is unreasonable. In Scots law, as a promise is a unilateral obligation requiring no reliance, this reasoning is not possible. Rather, counsel may argue that a promise has been made entirely outside the contract, and if the wording is sufficiently clear, a court should accept the argument. This point appears not only in Krupp Uhde but also in the quite similar case of Ballast Plc v Laurieston Properties Ltd., ${ }^{146}$ as well as other authorities. ${ }^{147}$ On the other hand, as Lady Paton holds in Ballast, the proof of the promise needs to be quite clear. The courts will be 'looking for a commercially sensible construction' and will want some explanation as to why a reasonable person would think that a legally binding guarantee (as had been argued) had been made through, as in that case, a letter about a mechanism of payment. ${ }^{148}$ In this category of cases, therefore, we find Louisiana and Scottish courts exercised by similar concerns, and reaching similar results, although on somewhat different grounds.

Aside from these relatively fertile areas, cases can be found elsewhere. The classic category of family promises, though often unsuccessful, can still come in for treatment akin to promissory estoppel under the Scots doctrine of promise. ${ }^{149}$ Not all cases can be so neatly lined up into typical categories, however. Bathgate $v$ Rosie $e^{150}$ perhaps does not fit any category well; it involves seemingly quotidian facts that do not often make their way into the case law. A mother promised to pay for a window her son

\footnotetext{
146 [2005] CSOH 16 per Lady Paton.

147 McBryde, Contracts (n 35), at 20 \& nn 38-39 refers to the finding of guarantees and back letters as 'frequent,' although only one case is cited, East Anglian Electronics Ltd v OIS Plc 1996 SLT 808.

148 [2005] CSOH 16, para 105.

149 See De Lathouer v Anderson 2007 CSOH 54 per Lord Emslie; 2007 GWD 11-232. For less successful attempts, see the discussion of Smith $v$ Oliver and similar cases, supra, and in the family category, Countess of Cawdor v Earl of Cawdor 2007 CSIH 3 (10 Jan 2007) should also be mentioned.

1501976 SLT (Sh Ct) 16.
} 
had broken, and the law held her to her promise. One might be tempted to classify this promise as founded on a natural or moral obligation, which seems accurate enough, but it should be noted that a natural or moral obligation does not itself constitute the necessary promise. ${ }^{151}$ In any case, as a residual doctrine promissory estoppel and its cognates always have a variety of odd cases to settle. ${ }^{152}$ Lord Advocate v City of Glasgow DC may also fall into this residuum. ${ }^{153}$ Other cases involving public authorities, which may involve an indeterminate creditor or in any event a lack of a formal acceptance, might prove amenable to analysis as promise cases. This possibility is suggested by the Muckle Flugga Lighthouse Case, although the court there holds that the Commissioners of Northern Lighthouses are the creditors of a contractual obligation. ${ }^{154}$

Doubtless many cases, especially Scottish ones, have not been noticed here. Still, by Louisiana standards the Scottish case law, particularly on promise, seems almost vanishingly thin — even though the time under examination is doubled. I have concentrated on cases in Louisiana since article 1967 became effective in 1985, focusing in this particular paper primarily on cases from the past dozen years, when my earlier study was published. In Scotland I have looked for cases from the last fifty years or so. In the last dozen years there have been roughly fifty or sixty cases on promissory estoppel in

\footnotetext{
${ }^{151}$ McBryde, Contracts (n 35) para 2-04 (citing J W Soils (Suppliers) Ltd v Corbett, OH 13 Jan 1993 per Lord Weir).

${ }^{152}$ On the Louisiana side, see Law v City of Eunice 626 So2d 575 at 577-78 (La Ct App 3d Cir 1993) (criminal defendant's bargain with police officer: because a plea bargain does not create a conventional obligation, court hesitates on contract action but suggests detrimental reliance).

1531990 SLT 721.

${ }^{154}$ Commrs of Northern Lighthouses v Edmonston [1908] SLT 439, OH, per Lord Johnston. Professor MacQueen has pointed out to me that the jobs assigned to the promise doctrine could well be keyed to the lack of acceptance, which is one of its defining features. He suggests cases when no one can accept (a promise to an indeterminate or incapable person, or a non-entity), or when too many could accept (as with rewards), or when the acceptance comes after the promisor is dead, incompetent, or insolvent. This theory is thoroughly appealing but is also rather more coherent than what I have managed to find in the cases. Still, the idea could be imposed on them with a little creativity, or perhaps extracted from some of the judges' opinions.
} 
Louisiana. The entry on promise in the Stair Memorial Encyclopaedia (1996) cites only two cases from the last fifty years ${ }^{155}$ (with no supplemental entry), and Gloag (11th ed. 2001) another one. ${ }^{156}$ I have found more for this paper, relying partly on McBryde (3d ed. 2007) and some more general research, but the results have not been great, as can be seen above. Professor MacQueen has pointed out that the concept of unilateral promise is 'little utilised. ${ }^{157}$ On the side of statutory bar, the story is not much different; Elspeth Reid has observed 'surprisingly little litigation. ${ }^{, 58}$ The implication is not necessarily that the doctrine per se is different or differently used, as larger differences in litigation patterns may provide a better explanation. But it is certainly remarkable.

On this note a related point should be made. In the cases that there are, the courts are sceptical bordering on stingy on both sides of the Atlantic. The judges enforce the legal requirements in many cases stringently, one might even say with a vengeance. The facts of Advice Centre for Mortgages have already been mentioned, but the cases could be multiplied. Reliance must be clear, and if it is as referable to one state of affairs as another, the statutory element for bar is not met. ${ }^{159}$ Even when the reliance is clear, it needs to be 'reasonable' under the statute, but the judicial view of reason seems to demand impeccable attention to detail. In Ben Cleuch Estates Ltd. v Scottish Enterprise ${ }^{160}$ the tenant held an option from the lessor, Ben Cleuch Estates Ltd. Various invoices, correspondence, and emails, however, came from Bonnytoun Estates Ltd, a subsidiary of Ben Cleuch, and the tenant sent its notice of exercise of the option to

\footnotetext{
${ }^{155}$ Bathgate v Rosie 1976 SLT (Sh Ct) 16.

${ }^{156}$ Hunter v Bradford Property Trust 1970 SLT 173.

${ }^{157}$ MacQueen \& Thomson, Contracts (n 35) para 2.61.

${ }^{158}$ E Reid "Personal Bar: Three Cases” (2006) 10 EdinLR 437 at 437.

${ }^{159}$ Tom Super Printing Supplies Ltd v South Lanarkshire Council 1999 GWD 31-1496.

160 [2006] CSOH 35.
} 
Bonnytoun. The court found the tenant's reliance on the invoices, correspondence, and emails unreasonable, holding that the tenant's solicitor ought to have checked more carefully on a lease with an annual rent of over $£ 200,000$. '[A]s so often, the plea of bar ended in failure.' 161

Similar concerns are apparent in the Louisiana case law. Some courts, at least, carefully enforce the requirements of a promise and reasonable, detrimental reliance on it. For that reason, many of the Louisiana cases deny recovery based on promissory estoppel. This paper is not the place for a careful assessment of the numerous Louisiana cases, but the trend of probing judicial scrutiny of promissory estoppel claims is clear enough. ${ }^{162}$ Perhaps nowhere is this trend as clear as in the at-will employment cases. An employee at will cannot reasonably rely on a different state of affairs, it seems, almost no matter what-absent an old-fashioned contract. ${ }^{163}$ This trend, observed in both Louisiana and Scotland, appears consistent with the studies of promissory estoppel more generally in the United States. ${ }^{164}$ While employment claims have met with particular hostility from

\footnotetext{
${ }^{161}$ Reid (n 158) at 437.

${ }^{162}$ Peoples State Bank v GE Capital Corp 2007 US App LEXIS 6055 (5th Cir 2007); Showboat Star Partnership v Slaughter 789 So2d 554 at 561-63 (La 2001); Moroux v Toce 943 So2d 1263 (La Ct App 2006); Lakeland Anesthesia, Inc. v United Healthcare of Louisiana 871 So2d 380 (La Ct App 2004); Marshall v First Bank \& Trust 848 So2d 660 (La Ct App 2003); Miller v Miller 817 So2d 1166 (La Ct App 2002); Butler v Sudderth 784 So2d 125 (La Ct App 2001); Jackson v Lare 779 So2d 808 (La Ct App 2000). On the promise requirement, see Roxco Ltd v Harris Specialty Chems 85 Fed Appx 375 (5th Cir 2004) (disclaimer); Peoples State Bank, supra, as well as some treatment of the question in Shreveport Plaza, LLC v Dollar Tree Stores, Inc 196 Fed Appx 320 (5th Cir 2006); Brookshire Bros Holding, Inc v Total Containment, Inc 2006 US Dist LEXIS 46061 (D La 2006); Freeman Decorating Co v Encuentro Las Americas Trade Corp 2005 US Dist LEXIS 18313 (D La 2005); Dorsey v N Life Ins Co 2005 US Dist LEXIS 17742 (D La 2005); LeMarie v Lone Star Life Ins Co 2000 US Dist LEXIS 16595 (D La 2000); Ark Entertainment, LLC v C J Gayfer \& Co 2000 US Dist LEXIS 3867 (D La 2000); Serv Steel \& Pipe v Guinn's Trailer Sales, Inc 850 So2d 902 (La Ct App 2003); see also Miller v Loyola Univ of New Orleans 829 So2d 1057 (La Ct App 2002).

${ }^{163}$ May v Harris Mgmt Corp 928 So2d 140 (La Ct App 2005) (note dissent's point that majority was sidetracked into consideration analysis); Robinson v Healthworks Intl 837 So2d 714 (La Ct App 2003); Trigg v Pennington Oil Co 835 So2d 845 (La Ct App 2002); McJamerson v Grambling State Univ 769 So2d 168 (La Ct App 2000).

${ }^{164}$ DeLong (n 111).
} 
the bench, the courts seem keen more generally to assure that promissory estoppel remains in its secondary status, safely behind contract.

Even aside from reliance issues, which after all are not relevant in the Scots law of promise, the attitude is the same. Possibly the best illustration of this attitude is the very recent but unbelievably picturesque case of Countess of Cawdor v Earl of Cawdor. ${ }^{165}$ Apparently there has been a long-running dispute between the dowager countess and her step-son the earl and thane. ${ }^{166}$ At issue in this case were some pensionfund transfers arranged by the trustees with respect to the countess and her husband, the late earl. The pension trustees said at a meeting that they planned to effect the transfers. The earl then died, and the trustees and the dowager countess with the apparent consent and help of the new earl completed some but not all of the transfers. The court had to decide what would happen with the other contemplated transfers, and the countess claimed that the trustees had promised to effect all of them. The meeting had been formal, the trustees had taken legal and financial advice, and a written minute was duly entered and signed.

Nevertheless, Lord President Hamilton quoted Stair’s careful distinctions with respect to unilateral promises. Neither desire nor resolution is enough to constitute an obligation, the Lord President observed, but some greater exercise of the will is required: a promise. A legally binding promise was certainly possible, as counsel suggested, based on the leading case of Macfarlane v Johnston. ${ }^{167}$ But Lord President Hamilton's reading of the minute did not suggest this level of commitment by the trustees, 'but rather an

\footnotetext{
1652007 CSIH 3 (10 Jan 2007) per Hamilton LP.

${ }^{166}$ See Terri Judd “Heir of Macbeth Loses Legal Battle in Cawdor Castle Feud” in Independent (8 Nov 2002).

167 (1864) 2 Macph 210, 36 Jur 574.
} 
intention, in the light of the advice received, to make in due course a transfer.' This intention was a plan but not a promise. ${ }^{168}$ The courts exercise great care before they construe people into legally binding obligations, whether they be trustees resolved to transfer significant monies or a simple doctor with a desire to reassure a patient. ${ }^{169}$

\section{E. THEORETICAL DEDUCTIONS}

\section{(1) The Nature of Liability}

Putting together Scottish and Louisiana law has thrown a few points into relief, not all of which could be mentioned above. The most prominent is how the theoretical underpinning of promissory liability differs between the systems, based largely on the history and source of the doctrine, and possibly (tenuously?) on the moral commitments of the legal systems. Scots law, it will be recalled, largely has drawn its law of promise from Stair, who in turn drew on canon law and (less clearly) the Scottish common law and the ius commune, to the exclusion of civil law. Although Stair disclaimed the notion that every act of will could give rise to an obligation, he still came down firmly with the thinkers who grounded liability on consent or will. That was his ground, and not the more delictual notion of reliance. This theoretical basis is delineated unusually clearly because not even acceptance is required, much less reliance. Of course on the personal bar side the tort notions are more prevalent, and Stair's treatment of promise already recognized this idea by noticing that there could be liability even in the absence of a promise if a resolution (as opposed to a promise) 'be holden forth to assure others. ${ }^{, 170}$ But this exception takes little from the main point, for with a robust law of promise there is little

\footnotetext{
168 The key paragraphs are 14-17 in Cawdor.

${ }^{169}$ Dow v Tayside University Hospitals NHS Trust 2006 SLT (Sh Ct) 141 at 145.

170 Stair, Inst I.10.2.
} 
need for promissory estoppel or personal bar, ${ }^{171}$ except in cases where a lack of formalities or some other defect gets in the way.

The Louisiana side is weighted in the other direction. Certainly the promise is crucial, and the obligation may therefore be said to be based on consent and the individual will. Indeed, the early draft legislation recognizes that a basis for introducing promissory estoppel into the Civil Code is that the move would appropriately validate 'the binding force of a unilateral declaration of will.' ${ }^{172}$ And the prominence of promise as the basis for liability has led to formal characterization of the liability as contractual rather than delictual. The placement of the key provision in the Civil Code articles on contracts in general, and even in the article on cause in particular, shows this choice, and the courts have generally followed this formal allocation. ${ }^{173}$

Despite all of this, though, the Louisiana law seems decidedly delictual in comparison to the Scottish law of promise. The doctrine, generally called 'detrimental reliance' in Louisiana, is all about the promisee's reliance. Although the early draft legislative document mentioned the importance of the (promisor's) will, delictual ideas were the chief justification for the introduction of promissory estoppel. ${ }^{174}$ Louisiana, after all, took its law not from the lawyers of the Church, concerned for the soul of the promisor, but from the Restatement of the American Common Law, concerned with equities that had to be recognized when the requirement of consideration or the disappearance of the seal visited injustice on relying promisees. Given the equitable nature of these concerns, to protect against the harm done to the promisee, the reliance is

\footnotetext{
${ }^{171}$ McBryde, Contracts (n 35) para 2-02.

172 Apr 1979 Draft (n 98) at 6-7.

${ }^{173}$ Stokes v Georgia-Pacific Corp 894 F2d 764 at 770 (5th Cir 1990); Flynn v Nesbitt 771 FSupp 766 at 768 (E D La 1991).

${ }^{174}$ Apr 1979 Draft (n 98) at 7.
} 
required every bit as much as the promise, and the reliance must be reasonable and detrimental. The courts have shown themselves quite willing to enforce these requirements, and while it can hardly be said that the liability is exclusively delictual, it is hardly based on consent alone. The element of tort in Louisiana law is quite strong in comparative terms.

\section{(2) Formalities and Their Functions}

Interestingly, Scotland and Louisiana made similar moves at roughly the same time, between 1985 and the early 2000s. Scotland during that period moved away from its requirement of a writ or oath for a promise, a requirement that did not admit an exception even if there was detrimental reliance. At the same time the Louisiana Civil Code and the case law interpreting it recognized a reliance based exception to some formal requirements, although not all of them. Too much can be made of similar moves at similar times, and cries of convergence are sometimes too swiftly voiced. The fact of the moves and their timing, though, should at least be recorded, and some of the implications considered.

When admitting some device to circumvent formal or other requirements for promises, the courts in Louisiana and Scotland have shown great care, as those requirements are typically thought to serve some important function. Typically American thought, following Lon Fuller, turns to evidentiary, cautionary, and signalling or channelling functions. ${ }^{175}$ Stair expresses the same idea, although without breaking it down into particular functions aside from the avoidance of mistakes. ${ }^{176}$

\footnotetext{
${ }^{175}$ L L Fuller “Consideration and Form” (1941) 41 ColumLRev 799 at 800-03.

176 Stair, Inst I.10.4.
} 
Let us begin with the evidentiary function. Writing serves as clear evidence of what was said, and whether it was indeed a promise. It is not obvious whether Stair (or the Scottish courts) recognize as much, but reliance can do the same, albeit less clearly. Reliance is probative to a degree, as substantial reliance seems less likely in the absence of some commitment. The reliance becomes quite probative if it occurs with the knowledge, and perhaps even cooperation, of the promisor.

The ‘cautionary' (in the American sense, having nothing to do with suretyship) and signalling or channelling functions are related, but significantly different. A writing and a fortiori an authentic act before a notary and witnesses should focus the attention of the promisor, assuring that he makes a commitment only after acting with appropriate deliberation. The Scottish Law Commission was certainly sensitive to this point, ${ }^{177}$ and it is recognized (although not by that name) in current case law. ${ }^{178}$ In addition, a writing or authentic act demarcates the promise as a legally binding one, not only cautioning the promisor but signalling to the world in general, and the courts more particularly, that the promisor intended to enter into the channel of legally binding relations, rather than the typical informal and unenforceable channel where human relationships are governed without the intervention of legal compulsion.

In some ways each of these functions can be seen as protecting promisors. Promisors are thus prevented from acting too hastily and inconsiderately, and they are protected from misconstruction of their words and actions. Their position with respect to legal relationships is clarified. But some of these functions can be otherwise served, and a

\footnotetext{
${ }^{177}$ Report on Requirements of Writing (Scot Law Com No 112, 1988) paras 2.21, 2.24; see also MacQueen (n 54) at 2 (construing Constitution and Proof of Voluntary Obligations and Authentication of Writings (Scot Law Com Consultative Memo No 66, 1985)).

${ }^{178}$ McEleveen v McQuillan's Ex'x 1997 Sh Ct 46 emphasises cautionary functions especially at 48, while recognizing evidentiary and signalling functions as well, e.g., at 50.
} 
recognition of that fact can aid the promisee. A court might hold, for instance, that where there is enough reliance by the promisee with the knowledge and cooperation of the promisor, then the promisor has received all of the protection it needs. If the promisor let a tenant enter the premises, accepted rent, and acquiesced in changes to the property, one might think that the landlord knew what it was doing and was willing for there to be legal effects. ${ }^{179}$ Finding the function of the required formality (writing) to be satisfied in such a case by this kind of reliance, the court might hold for the tenant. The Scottish courts, however, have seemed hesitant.

The case law thus indicates that Scottish courts may be particularly concerned with signalling or channelling functions, which protect the parties, the courts, and society in general. If we read the stinginess of the case law to require a clear demarcation between friendly and even cooperative relations and legal ones, the cases make better sense. Although the landlord admitted the tenant, the parties were not yet ready to be bound. A writing is simple enough, and 'ordinary, ${ }^{180}$ hardly unusual in an age of forms and general literacy. Friendly banter between friends on their way out for an evening of bingo should not be turned into a contractual relationship about the splitting of winnings unless the court examines the circumstances with great care. ${ }^{181}$ Even trustees in a formal meeting may announce and record their intentions, and carry some of them out, without being held committed to all of them. ${ }^{182}$

\footnotetext{
${ }^{179}$ The discussion is based on Advice Centre for Mortgages v McNicoll [2006] CSOH 58, 2006 SLT 591 per Lord Drummond Young.

${ }^{180}$ Stair himself! Inst I.10.4.

${ }^{181}$ The general rule and the possibility of exception based on considerable testimonial proof is shown in Robertson $v$ Anderson, admittedly a contract case, but showing the same concerns. 2003 SLT 235 (IH 5 Dec 2002).

${ }^{182}$ Countess of Cawdor v Earl of Cawdor 2007 CSIH 3 (10 Jan 2007) per Hamilton LP.
} 
A commitment, then, may be possible, but its clarity, it seems, needs to be unmistakable. Perhaps this is saying no more than Erskine said in the eighteenth century, ${ }^{183}$ but that the dictum remains as important now as then is remarkable. If it is true that omne verbum de ore fideli cadit in debitum, ${ }^{184}$ then the verbum must be ever so clear, and fideli must carry a heavy and manifold meaning. It seems that Stair more aptly described the landscape, in Louisiana as well as Scotland, with his own words: 'But it is not every act of the will that raiseth an obligation. ${ }^{\text {,185 }}$

\section{(3) Doctrines with Elbows in a Jostling World}

The Scots law of promise, augmented by the law of personal and statutory bar, raises again a question in Louisiana that arose during the revision of the Code. Does Louisiana need promissory estoppel? The answer at the time was that Louisiana had sufficient doctrine to take care of promissory estoppel jobs, but that promissory estoppel would provide a more direct approach to the typical problems. ${ }^{186}$ It might be added that promissory estoppel might be a more approachable doctrine, the mix in Louisiana being such that the Restatement is in far easier reach than sources on venire contra factum proprium or culpa in contrahendo. This would seem particularly true for adjustments in commercial relationships that are certainly not donative but that also are not easily classified as onerous or synallagmatic contracts (e.g., undertakings to pay a counterparty’s financier instead of the counterparty itself, as in Boyte or Krupp Uhde). ${ }^{187}$

\footnotetext{
${ }^{183}$ III.3.90, cited in Hogg \& MacQueen (n 53) at 2, 6.

${ }^{184}$ Stair so recites the canon law, which he adopts. Inst I.10.7 (citing C.1 \& 3 de pactis [C.2, 3, 1 and 3]).

${ }^{185}$ Ibid I.10.1; see also Saúl Litvinoff "Still Another Look at Cause” (1987) 48 LaLRev 3 at 4 ('In spite of emphatic declarations ... the fact is that consent alone is not enough to engender legal binding force.'). ${ }^{186}$ Apr 1979 Draft (n 98) at 7.

${ }^{187}$ Boyte v Wooten, 2006 US Dist LEXIS 45098, at *12-*16 (D La 2006); Krupp Uhde GmbH v Weir Westgarth Ltd per Lord Eassie 31 May $2002(\mathrm{OH})$.
} 
Promissory estoppel has elbows, and it elbowed its way into Louisiana. Perhaps fear about those elbows is what has caused the courts to keep the doctrine in careful check.

The doctrine may thrust its elbows in other directions. Promissory estoppel in Louisiana may stifle innovation in recognizing the efficacy of declarations of the will that could be enforceable without reliance. The same idea carries greater weight in Scotland, but in the other direction. Recognition of a legally enforceable promise, with the relatively permissive requirement of a simple writing (as opposed to a deed), seemingly slowed the development of reliance-based exceptions. They were not recognized until 1995, and the courts still seem reluctant to put them into play.

Perhaps it is not strictly relevant here, but this result seems too bad. Care about putting a party into a legally binding relationship is understandable. A promisor ought to be cautioned, and the courts ought to have good evidence, and the line between the merely social and the coercively legal should be brightly marked. But these statements are ideal, and justice involves balance. The law might intervene into a person's natural liberty not only because of consent but also because of harm to another. Certainly the case for legal interference is stronger when there is both consent by the defendant and harm to the plaintiff, as suggested, at least, by Fuller and Perdue's construction of Aristotle. ${ }^{188}$ Accordingly, justice may be served if there is heavy reliance, with the foresight, and perhaps even knowledge and cooperation, of the promisor, even if the promise is not stated in ideal terms.

\footnotetext{
${ }^{188}$ Aristotle, Nicomachean Ethics 1132a-1132b, construed in L L Fuller \& W R Perdue Jr “The Reliance Interest in Contract Damages” part 1 (1936) 46 YaleLJ 52 at 56-57. I here assume that Aristotle’s point, as understood and expounded by Fuller and Perdue, is sound. Although unraveling its implications may lead to questions and doubts, I do not treat them here. Cf. J Gordley, "Enforcing Promises” (1995) 83 CalLRev 547, and more fully, J Gordley, The Philosophical Origins of Modern Contract Doctrine (1991), and more generally still, J Gordley, The Foundations of Private Law (2006). Compare McBryde (n 1) at 55 (on Molina), 66 (on St Thomas Aquinas).
} 


\section{F. CONCLUSION}

The mixed nature of the law in Scotland and Louisiana has proved fertile for comparison. The usual stories become more intricate as they involve elements from different places, with complicated histories and traditions and languages. At the same time, the sensible concerns of courts applying different but analogous doctrines can be observed, across jurisdictional boundaries and even across seas. Pervading the complex learning and borrowing are similar notions of justice and congruent policies oriented around practicality. When deciding at what point, in the absence of an ordinary contract, persons have bound themselves to each other, these sorts of concerns ring especially clearly. This, I hope, is what we have been able to hear as we have hunted for promissory estoppel in places where it is rather an exotic beast.

$\backslash$ Publish\Edinburgh\EdinArt4 